\title{
Volatilidade dos Fluxos Internacionais de Capitais e a Oferta de Crédito na Economia Brasileira entre 1995 e 2009
}

\section{Volatility of International Capital Flows and Credit Supply in the Brazilian Economy between 1995 and 2009}

\author{
Vanessa da Costa Val Munhoz* \\ Lidiane Cassiano Gaspar**
}

\begin{abstract}
Resumo: O objetivo deste trabalho é verificar a relação entre a volatilidade dos fluxos internacionais de capitais e o volume de crédito ofertado na economia brasileira entre 1995 e 2009. Argumenta-se que, durante crises internacionais, quando há fuga de capitais estrangeiros do Brasil, os bancos aumentam a sua preferência pela liquidez e diminuem a oferta de crédito na economia doméstica. Ademais, a existência de títulos públicos brasileiros rentáveis e facilmente negociáveis em mercados secundários de papéis permite ao sistema bancário brasileiro obter elevados níveis de rentabilidade a partir de uma composição de portfólio flexível. Desse modo, com base na análise de dados das subcontas financeiras do balanço de pagamentos brasileiro e do consolidado bancário, verifica-se que mesmo não sendo direta a relação entre os fluxos internacionais de capitais e a oferta de crédito na economia doméstica, a atuação dos bancos no Brasil está condicionada às flutuações cíclicas pelas quais a economia internacional passa.
\end{abstract}

Palavras-chave: Fluxos de capitais. Preferência pela liquidez dos bancos. Oferta de crédito.

Abstract: The aim of this paper is to verify the relation between the volatility of international capital flows and the credit volume presented in the Brazilian economy from 1995 to 2009. The main argument is that in moments of reversion of expectations and international crises, when there is foreign capital flight, the banks increase their liquidity preference and reduce the credit supply in the domestic economy. Moreover, the profitability of Brazilian public bonds and its easier negotiation in secondary markets papers allows that the Brazilian banking system obtains high profitability levels from a flexible composition portfolio. Thus, by analyzing data from

\footnotetext{
* $\quad$ Professora do Instituto de Economia da Universidade Federal de Uberlândia. E-mail: vanessacostaval@ie.ufu.br

* * Graduada em Ciências Econômicas pela Universidade Federal de Uberlândia. E-mail: lidi.gaspar@gmail.com
} 
the financial account of the Brazilian balance of payments and the consolidated banking data, this paper verifies that, although the relationship between international capital flows and credit supply in the domestic economy is not direct, the role of banks in Brazil is subject to cyclical fluctuations in the international economy.

Keywords: Capital flows. Banks liquidity preference. Credit supply.

JEL Classification: E51; F32; F36; G15.

\section{1 lntrodução}

Os fluxos de capitais estrangeiros direcionados ao Brasil, especialmente a partir da década de 1990, são guiados por expectativas e movimentos especulativos, seguindo momentos em que há abundância ou escassez de liquidez no mercado financeiro internacional. Em conformidade com a tendência deste mercado e a partir da dinâmica concorrencial, o sistema bancário brasileiro passou a operar através de práticas arriscadas, como a captação de recursos via depósitos a prazo, com liquidez diária, e a oferta de empréstimos vinculados a operações do mercado de capitais ${ }^{1}$, sofrendo os efeitos desestabilizadores das reversões de expectativas dos agentes que atuam no sistema financeiro internacional. Dessa forma, os bancos, diante da incerteza quanto à reversão desses ciclos de liquidez e, consequentemente, quanto à captação de recursos externos, podem frear a oferta de crédito, ou até mesmo paralisá-la, dependendo do grau de sua preferência pela liquidez.

Sob este contexto, o propósito deste trabalho é analisar a relação entre a volatilidade dos fluxos de capitais estrangeiros, o papel dos bancos na captação de recursos e o volume de crédito ofertado na economia brasileira no período que vai de 1995 a 2009. Especificamente, pretende-se verificar se existe uma relação direta e/ou indireta entre a dinâmica dos fluxos internacionais de capitais e o volume de crédito doméstico.

A hipótese básica é que em momentos de reversão de expectativas e crise internacional, quando há fortes fugas de capitais para os países centrais em busca de qualidade de investimentos, os bancos - dependentes de recursos estrangeiros para captação de recursos - ficam fragilizados e aumentam a sua preferência pela liquidez, diminuindo a oferta de crédito na economia doméstica. Além disso, os títulos públicos brasileiros são altamente rentáveis e facilmente negociáveis em mercados secundários de papéis, permitindo ao sistema bancário brasileiro obter elevados níveis de rentabilidade a partir de uma composição de portfólio flexível e,

1 Uma prática recente e que veio à tona diante da crise de 2007/2008, provocando uma série de falências, foram os empréstimos as empresas acoplados aos derivativos de dólar. Para detalhes ver Adachi e Balarin (2008). 
assim, funcionando como um "colchão de liquidez" em momentos de instabilidade, mas não sendo "descartados" em momentos mais estáveis.

Há vários trabalhos que tratam de forma indireta as relações entre crédito e volatilidade dos fluxos de capitais, entretanto uma pequena minoria analisa de forma mais direta tal relação. Assim, este estudo justifica-se, primeiramente, por haver espaço para essa discussão, haja vista os movimentos mais bruscos dos fluxos internacionais de capitais, observados na última década e o consequente impacto sobre os mercados financeiros de países periféricos (que não emitem moeda forte). Ademais, o trabalho foca a oferta de crédito, um importante mecanismo da dinâmica econômica, visto que este elemento é o grande canalizador de recursos para que os investimentos possam ser efetivados. A justificativa para a análise do período de 1995 a 2009 se dá por se tratar de um período pós inflacionário e por abarcar o período de crise financeira mais recente.

Além desta breve introdução, o trabalho é composto por mais 5 seções. A segunda seção dedica-se ao embasamento teórico do trabalho, cujo referencial é a abordagem pós keynesiana, desenvolvida a partir dos estágios do desenvolvimento bancário e sua importância para a atividade econômica por meio da oferta de crédito. A terceira seção está reservada para o exame da dinâmica dos fluxos internacionais de capitais e seus impactos sobre a economia brasileira, ao passo que a quarta seção trata a oferta de crédito no Brasil, entre 1995 e 2009; completando a estrutura de análise para a discussão da relação entre volatilidade dos fluxos internacionais de capitais e oferta de crédito, realizada na quinta seção. Por fim, à guisa de conclusão, são tecidas algumas considerações finais na sexta seção.

\section{Estágios do Desenvolvimento Bancário, Papel dos Bancos na Atividade Econômica e o Racionamento/Oferta de Crédito}

A análise sustentada por este trabalho parte da perspectiva keynesiana, segundo a qual o ponto de partida para a discussão da oferta de crédito em uma economia monetária de produção e seu impacto sobre a dinâmica econômica é o tratamento da moeda. Esta desempenha importante papel na influência sobre as decisões dos agentes econômicos, sendo não neutra no curto e no longo prazo. Em que pese esta importância, destaca-se que a forma como a moeda é criada e introduzida na economia depende do grau de desenvolvimento do sistema bancário. Como mostrado por Keynes (1930), a evolução deste sistema transforma os bancos de meros intermediários de poupanças em ofertantes de meio de pagamento, com capacidade de criar crédito independente de depósitos prévios.

Partindo desta ideia, Chick (1986) elaborou uma teoria acerca dos estágios do desenvolvimento do sistema bancário a partir da evolução do sistema inglês. Para a autora, o sistema bancário se desenvolveu de forma contínua, não apresen- 
tando rupturas abruptas entre os cinco estágios definidos por ela. Nos primeiros estágios do desenvolvimento do sistema bancário, os bancos atuam como meros intermediários entre poupadores e investidores, sendo que o crédito é limitado pelo volume de depósitos. Os bancos se limitam a redistribuir o crédito existente entre os agentes. Nos estágios posteriores, a relação de causalidade entre depósitos e crédito se inverte e o volume de empréstimos passa a depender do comportamento dos demandantes e ofertantes de crédito, determinado, por sua vez, pela preferência pela liquidez dos mesmos, não sendo mais limitado pela quantidade de depósitos. A oferta de moeda se torna endógena e as autoridades monetárias deixam de ter controle sobre a liquidez do sistema. Diante disso, percebe-se que os bancos possuem um papel fundamental na economia, já que criam meios de pagamento endogenamente e podem emprestar mais recursos do que a sua posição de reservas tecnicamente lhes permitiria. Assim, o volume de crédito concedido é influenciado pelas condições da economia, que determinam a preferência pela liquidez e o grau de desenvolvimento bancário.

Nesse sentido, o sistema bancário para Keynes e seus seguidores tem um papel fundamental, pois é ele que disponibiliza os recursos para a sequência do processo econômico, adiantando o montante necessário à decisão de investir. Dessa maneira, os bancos possuem um papel ativo no que se refere ao direcionamento de recursos para a realização de investimentos e, consequentemente, ao desenvolvimento da economia. Mais do que meros intermediários passivos de recursos, os bancos são capazes de criar crédito independente da existência de depósitos prévios, por meio da criação ativa de moeda bancária. Ademais, têm um papel essencial na determinação das condições de financiamento de uma economia ao estabelecer o volume e as condições sob as quais o crédito é ofertado (PAULA, 2006).

Outrossim, na abordagem pós-keynesiana, os bancos são vistos como tomadores de decisões e, assim como os outros agentes econômicos, têm como principal objetivo a obtenção de lucro na forma monetária; operando em um ambiente de incerteza, de forma que ao tomarem suas decisões consideram suas expectativas com relação ao futuro e procuram alocar seus recursos de acordo com sua preferência pela liquidez e suas avaliações de riqueza financeira. Nesse sentido, os bancos precisam decidir de que forma seus recursos serão alocados no seu portfólio de acordo com o trade off entre liquidez e rentabilidade ${ }^{2}$. Assim, a expansão ou contração da oferta de moeda é resultado da escolha de que ativos comprar e que obrigações emitir.

As expectativas dos bancos sob as condições de incerteza têm um papel fundamental na determinação da composição do seu portfólio de aplicações. Eles

2 Os bancos sempre se deparam com decisões de conceder ou não créditos para compor seu ativo e, por isso, têm sempre que comparar as combinações entre risco e rentabilidade oferecidas pelas operações. Quanto maior for o risco, maior a sua rentabilidade, porém mais ilíquido. Da mesma forma, quanto menor for o risco, menor a rentabilidade e mais líquido será, ou seja, o risco é compensado pelo retorno que o ativo oferece. 
podem demandar aplicações mais líquidas, apesar de menos lucrativas em função de um aumento na sua preferência pela liquidez, o que resulta num redirecionamento em sua estrutura de ativos. A moeda legal e os ativos líquidos representam um instrumento de proteção à incerteza e de redução dos riscos intrínsecos à atividade bancária. A retenção desse tipo de ativos permite aos bancos manter opções abertas, inclusive para especular no futuro. Desse modo, os bancos com alta preferência pela liquidez podem não acomodar passivamente a demanda por crédito, visto que buscam comparar os retornos esperados com os prêmios de liquidez de todos os ativos. Diante disso, as proporções em que as aplicações são divididas passam por flutuações, refletindo as expectativas dos bancos quanto à rentabilidade e liquidez de seus ativos. Sendo assim, a evolução do crédito tende a ser procíclica, sobretudo se o sistema bancário for essencialmente constituído por instituições privadas com fins lucrativos (FREITAS, 2009).

A preferência pela liquidez justifica a existência de racionamento de recursos, que também é afetada pela qualidade e custo das informações disponíveis. Isso significa que a oferta de crédito pode ser restringida devida uma maior preferência pela liquidez dos bancos, independente do verdadeiro risco relacionado ao empréstimo bancário e dos retornos que são esperados sobre projetos de investimento. Além disso, a existência de racionamento de crédito é influenciada por outros fatores que definem as expectativas dos agentes com relação ao futuro e a confiança destes em relação às suas próprias projeções. Para minimizar o problema do crédito racionado, os pós-keynesianos sugerem que medidas visando somente resolver as falhas de mercado para que os empréstimos fluíssem, como defendem os novos-keynesianos ${ }^{3}$, não seriam suficientes. O problema tem que ser pensado de um modo mais amplo; ou seja, deve-se levar em consideração não somente a oferta de recursos, mas também a demanda por fundos, sendo os dois afetados pela incerteza e pela expectativa dos agentes com relação ao futuro.

A questão que se coloca como essencial para explicar o comportamento dos bancos no que tange à oferta de crédito e sua relação com os fluxos internacionais de capitais é que o sistema capitalista tem um comportamento estruturalmente instável, sujeito ora a ondas de pessimismo, ora a excessos de confiança, levando aos movimentos dos ciclos econômicos. Ao desenvolver a hipótese de instabilidade financeira, Minsky (1986) formula a ideia de que as

3 Grande parte da literatura que trata do racionamento de crédito é de caráter novo-keynesiano, baseada sobretudo no estudo de Stiglitz e Weiss (1981). Tais autores desenvolveram um modelo em que o crédito é racionado devido à presença de assimetrias de informação. De acordo com essa linha de pensamento, os tomadores de empréstimos podem saber mais que os credores sobre suas competências em relação aos seus planos para usar o dinheiro emprestado ou sobre a sua capacidade de pagamento da dívida contraída. A resposta ótima dos emprestadores é, então, restringir o crédito e/ ou utilizar mecanismos sinalizadores para separar os tomadores de empréstimos. Por sua vez, conforme a teoria que embasa este trabalho (a pós keynesiana), o racionamento de crédito nada tem a ver com problemas de informação, mas sim com a preferência pela liquidez dos bancos.

MUNHOZ, V. C. V.; GASPAR, L. C. Volatilidade dos fluxos internacionais de capitais... 
fases de otimismo vêm acompanhadas de um crescimento da fragilidade. Isso porque nesses períodos se ampliam os investimentos e o grau de endividamento, além disso, segue-se depois dos períodos de otimismo, uma crise que aparece como desdobramento da própria fragilidade, já que esta tem como efeito uma reversão das expectativas, uma diminuição do crédito e um consequente comprometimento da atividade produtiva.

Assim, o ciclo na economia, para Minsky (1986), é financeiro, de forma que choques externos ao sistema financeiro apenas agravam os desequilíbrios e, isso ocorre, porque são as decisões dos bancos (e sua capacidade de conceder créditos) que criam condições para o funcionamento cíclico da economia, já que influenciam diretamente o volume de recursos que será destinado aos investimentos produtivos, determinando o nível de atividade e o volume de emprego, renda e produção na economia.

Em períodos em que o ciclo econômico se mostra favorável os bancos estão dispostos a ofertar um maior volume de recursos às firmas, ou seja, têm uma menor preferência pela liquidez e acabam aumentando o seu grau de alavancagem, pois adotam posturas menos cobertas. Quando o ciclo se reverte, os bancos aumentam sua preferência pela liquidez e passam a restringir o crédito ao mesmo tempo em que as empresas passam a necessitar de mais recursos para fazer frente aos compromissos financeiros contraídos na fase ascendente do ciclo. Assim, ao passo que na fase expansionista do ciclo econômico os bancos têm esse papel central de ofertar o crédito necessário para as empresas, na fase descendente do ciclo os bancos passam a ter um novo papel: o de amplificar o quadro de crise. Isso ocorre porque, uma vez que as estratégias defensivas adotadas pelos bancos resultam em uma diminuição da oferta de crédito, a rolagem da dívida pode ser inviabilizada por parte das empresas não-financeiras.

Ademais, enquanto antes dos anos 1960 os bancos operavam administrando seus portfólios de aplicações, com os processos de desregulamentação financeira e a intensa concorrência interbancária produzida por ela, eles se viram forçados a inovar na forma como seus recursos são captados, a partir da década referida. Assim, eles passam a operar no sentido de aumentar seus graus de alavancagem e, consequentemente, auferir maiores lucros, através de novos produtos e instrumentos financeiros que permitiram aos bancos captar recursos de outras formas que não fossem somente depósitos à vista. Através das inovações financeiras, os bancos podem, ainda, obter maior spread entre a taxa de aplicação e a taxa de captação.

Essas inovações financeiras, segundo Carcanholo (2001) e Freitas (2009), têm influência tanto sobre o montante quanto sobre o perfil dos recursos captados, o que permite aos bancos contornar as restrições e regulações impostas pelas autoridades monetárias sobre as reservas bancárias. O Banco Central pode, assim, 
ter os seus objetivos de gestão de liquidez da economia contrariados pelas estratégias adotadas pelos bancos na administração de seus ativos e passivos. E os novos instrumentos e procedimentos contribuem, ainda, para ampliar a complexidade das estruturas financeiras e das relações entre os devedores e credores. O resultado disso é o aumento da instabilidade da economia potencializada pelos processos de desregulamentação e globalização financeira, além da liberalização dos fluxos de capitais. $O$ processo de globalização financeira, a partir da instauração de um mercado global unificado, permite às empresas industriais e financeiras contratar empréstimos ou aplicar fundos sem limites onde e quando quiserem, recorrendo aos diversos instrumentos financeiros existentes (PLIHON, 1995). Esses processos criam uma interface entre os mercados (monetário, cambial e de títulos) e os bancos centrais, de modo que as oscilações das expectativas dos agentes quanto à vulnerabilidade externa das economias torna a política econômica de um país dependente da dinâmica financeira dos capitais internacionais e das políticas econômicas dos outros países, em especial as dos países centrais.

Um exemplo dessa dependência é que uma crise internacional pode afetar o mercado de crédito doméstico mediante vários canais de transmissão, conforme verificamos em estudo do IEDI (2009). Uma retração das linhas de crédito internacionais tem impactos adversos tanto sobre os empréstimos bancários às empresas concedidos no país com base em funding externo - Adiantamentos dos Contratos de Câmbio (ACCs), repasses externos e financiamento às importações), como sobre a captação direta das empresas no mercado internacional (através de empréstimos bancários ou emissão de títulos). Dessa forma, os acontecimentos no mercado internacional, através dos influxos de capitais, afetam os bancos brasileiros por meio de dois modos: a) a partir dos ativos bancários, visto que os movimentos dos capitais estrangeiros afetam a concessão de crédito por parte dos bancos e; b) a partir dos passivos bancários, já que é possível captar mais ou menos recursos através do mercado estrangeiro.

Portanto, com base na perspectiva pós-keynesiana, este trabalho intenta mostrar como a natureza e a dinâmica volátil dos fluxos de capitais direcionados para a economia brasileira pode afetar o mercado de crédito doméstico, fazendo com que em momentos de crise e, consequente fuga de capitais à procura de qualidade, a oferta de crédito na economia doméstica seja restringida.

\section{A Dinâmica dos Fluxos Internacionais de Capitais e seus Impactos no Brasil}

A liberalização da conta financeira do balanço de pagamentos que ocorreu no final da década de 1980 em diversos países e, no Brasil, no início da década de 1990, associada ao arranjo macroeconômico delineado a partir da implantação 
do Plano Real (centrado na meta de estabilização de preços e âncora cambial), provocou um forte aumento dos fluxos de capitais direcionados para as economias emergentes. Entretanto, esses fluxos de capitais apresentam natureza volátil, que tomam a forma de ciclos, em que se encadeiam em fases de elevada liquidez seguidas por períodos de absoluta escassez. Para Farhi (2004), esses ciclos de liquidez são entrecortados por mini-ciclos, que acentuam a volatilidade e incerteza dos agentes, uma vez que não se pode prever suas durações e intensidades.

Desse modo, os fluxos de capitais voláteis contribuem para aumentar a fragilidade externa das economias domésticas, pois as mudanças súbitas das expectativas dos investidores internacionais podem resultar em drástica redução do nível de desempenho da economia. Uma mudança nas expectativas dos agentes econômicos é amplificada pelo comportamento "imitativo" dos demais agentes (comportamento de manada e efeito contágio), o que leva a um ataque especulativo sem que sejam considerados os "fundamentos" econômicos. ${ }^{4}$ Ou seja, quando a incerteza nos mercados financeiros aumenta os agentes tendem a prever a psicologia do mercado e não os lucros esperados dos ativos, tornando os mercados financeiros instáveis; sendo assim, o comportamento dos outros agentes é mais "importante" do que a condução da política econômica (GABRIEL; OREIRO, 2008).

Neste contexto, os efeitos instabilizadores dos fluxos de capitais voláteis se tornaram explícitos nas diversas crises cambiais e financeiras que eclodiram nos anos 1990 (destacam-se: a crise mexicana, 1994/95; a asiática, 1997; a russa, 1998; a brasileira, 1999; a turca e a argentina, 2001), de tal sorte que os ciclos de liquidez internacional afetam o volume e a direção dos fluxos de capitais destinados às economias emergentes, em especial ao Brasil.

No início dos anos 1990, sob o contexto da globalização financeira, um conjunto de mudanças institucionais possibilitou a ampliação do grau de abertura financeira da economia brasileira, permitindo a inserção dos agentes domésticos ao mercado financeiro internacional. Os investidores estrangeiros buscavam oportunidades de ganho em mercados mais arriscados, principalmente após a redução da taxa de juros básica dos Estados Unidos no início daquela década, o que fez com que o longo período de escassez de financiamento externo, que caracterizou os anos 1980, chegasse ao fim. Dessa forma, a abundância de capitais líquidos permitiu a implementação da reforma monetária necessária para o sucesso do Plano Real em 1994, sendo que essa abundância foi indispensável para a utilização da taxa de câmbio como âncora nominal. Nesse sentido, para que esses capitais

4 A literatura sobre o tema deste trabalho trata como fundamentos econômicos fatores como: crescimento econômico, relação dívida/PIB, núcleo da inflação, indicadores de endividamento externo e indicadores de vulnerabilidade externa, dentre os quais podemos citar: relação dívida externa líquida/exportações, relação dívida externa privada líquida/exportações, relação dívida externa pública líquida/exportações, passivo externo líquido/exportações, passivo externo de curto prazo/reservas totais. 
fossem atraídos para a economia doméstica, o país oferecia altas taxas de juros e a possibilidade de se adquirir ativos subvalorizados, principalmente com a perspectiva de ampliação do programa de privatização5 (CINTRA; PRATES, 2005).

Assim, com o intuito de verificar se existe uma relação direta e/ou indireta entre a dinâmica dos fluxos de capitais estrangeiros destinados à economia brasileira pós Plano Real e o volume de crédito ofertado na economia doméstica, mostra-se a partir daqui a evolução da dinâmica dos fluxos de capitais internacionais direcionados ao Brasil e o impacto da volatilidade desses fluxos. Para tanto, serão utilizados os dados da conta financeira do Balanço de Pagamentos brasileiro, bem como suas subcontas.

A análise da dinâmica dos fluxos de capitais será dividida em quatro períodos, a saber: a) Período I - 1995 a 1998: em razão de ser um período em que vigorou no Brasil o sistema de câmbio administrado; b) Período II - 1999 a 2002: em função de ainda se tratar de uma fase de relativa escassez de recursos internacionais destinados às economias emergentes; c) Período III - 2003 a 2006: em função de se tratar de um novo ciclo de liquidez internacional; d) Período IV - 2007 a 2009: por abranger a crise internacional recente.

\subsection{Período I - 1995 a 1998}

A abertura financeira da economia brasileira na década de 1990 permitiu que as barreiras que até então existiam aos investimentos de portfólio no mercado financeiro doméstico se reduzissem e ainda viabilizou o acesso de residentes às novas modalidades de financiamento externo, como emissão de títulos e ações no mercado internacional de capitais.

Assim, a partir da implementação do Plano Real, as contas externas brasileiras sofreram uma profunda alteração, de forma que na primeira fase do Plano Real (1995 - 1998), sob regime de câmbio administrado, a balança comercial tornouse negativa em US $\$ 5,6$ bilhões e as transações correntes, em US $\$ 26,4$ bilhões ou $3,4 \%$ do Produto Interno Bruto (PIB), sendo a entrada de investimentos em carteira fundamental para financiar o déficit em transações correntes (CINTRA; PRATES, 2005).

A entrada de um intenso fluxo de recursos na economia brasileira, nesse período, foi possível visto que no início da década de 1990 foi observado um momento de fartura de capitais privados direcionados dos países centrais para a América Latina aliada à adoção de elevadas taxas de juros. Entretanto, parte importante destes capitais se vinculava aos investimentos em carteira (Gráfico 1), que são fluxos que possuem um caráter mais especulativo e que buscam, continuamente, alta lucratividade em curto espaço de tempo.

Para detalhes acerca do programa de privatização dos anos 1990, ver Giambiagi e Além (2008).

MUNHOZ, V. C. V.; GASPAR, L. C. Volatilidade dos fluxos internacionais de capitais... 
Gráfico 1 - Brasil: evolução da conta financeira - 1995-1998

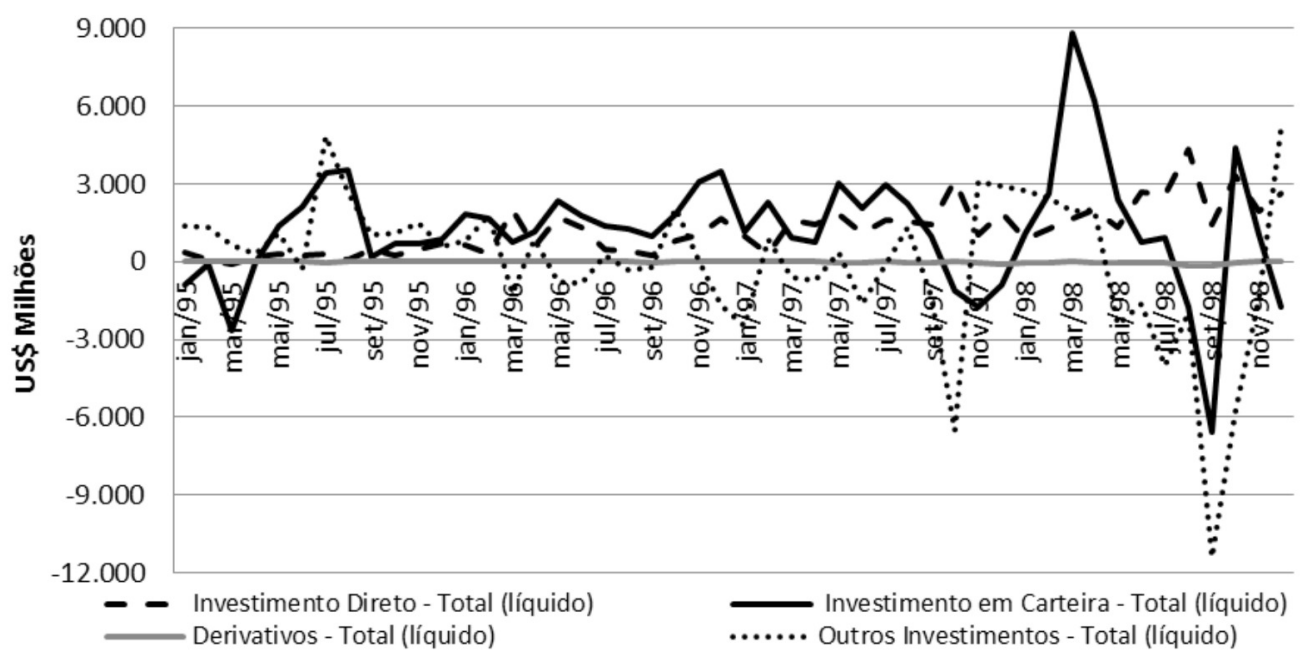

Fonte: Elaborado pelas autoras a partir de dados do Banco Central do Brasil.

Nesse período também é possível observar a elevada participação do investimento estrangeiro direto (IED) na conta financeira, que pode ser relacionado ao processo de privatização de empresas estatais, iniciado na década de 1980 e ampliado nos anos 1990. Ademais, podemos perceber uma pequena participação relativa dos derivativos na Conta Financeira.

Entre 1995 e 1998, o saldo da conta financeira variou entre US\$28.744 milhões (menor valor do período) e US\$33.514 milhões (maior valor do período). Isso porque, conforme já mostrado, foi um período em que ocorreram várias crises cambiais e financeiras, o que fez o país encerrar o ano de 1998 com um saldo pouco maior do que o início do período aqui analisado (US\$29.381 milhões). Assim, podemos notar que a crise do México no final de 1994 não teve grandes repercussões para o ano de 1995, fazendo com que o ciclo de liquidez iniciado no começo da década se mantivesse.

A crise mexicana pode não ter afetado a economia de modo tão significativo, mas significou o "início do fim" da fase de alta liquidez para as economias emergentes, que se encerra com a crise da Rússia em 1998. Após essa crise uma fase de redução de liquidez se iniciou, sendo marcada ainda pela deflagração da crise brasileira em 1999, dados os impactos negativos das sucessivas crises cambiais ocorridas no período. Ademais, a crise da Rússia aumentou a aversão ao risco dos investidores internacionais, fazendo com que eles adotassem posturas mais cobertas e seguras e, nesse contexto, o elevado déficit em conta corrente brasileiro desencadeou uma acentuada fuga de capitais, provocando forte redução nas reservas internacionais do país e forçando a adoção do regime de câmbio flutuante, como destacaremos a seguir.

Através do Gráfico 1, podemos ver que os momentos de reversão dos recursos, sobretudo de outros investimentos e de investimentos em carteira, coincidem com as crises que ocorreram nesse período: México (final de 1994/1995), 
Ásia (1997) e Rússia (1998); sendo que os investimentos diretos e os derivativos apresentaram um comportamento bem menos volátil neste período. Isso porque o investimento direto externo possui um caráter menos especulativo e são vinculados às perspectivas de crescimento econômico nos países de origem e de destino, bem como às estratégias das empresas transnacionais. Já o que possui maior peso na conta denominada outros investimentos são os fluxos de moeda e depósitos, o que faz com que a conta financeira seja dominada por capitais altamente voláteis, que se movem conforme as expectativas dos agentes econômicos. Dessa forma, a abertura financeira fez ainda com que a política monetária brasileira ficasse de certa forma limitada, visto que para atrair recursos para o fechamento do Balanço de Pagamentos e sustentar a política cambial, era necessário que a Autoridade Monetária elevasse cada vez mais a taxa de juros doméstica ${ }^{6}$, o que gera implicações diretas na dívida pública interna do país.

\subsection{Período II - 1999 a 2002}

No segundo período a ser analisado, temos uma redução da participação dos investimentos em carteira ao passo que os investimentos diretos passaram a desempenhar um importante papel (Tabela 1). A intensa entrada de recursos em tal subconta deve-se ao avanço do processo de desestatização nos setores de utilidade pública, com destaque para o setor de telecomunicações, e à onda de expansão ${ }^{7}$ de grandes corporações produtivas e financeiras, impulsionada por operações de fusão e aquisição.

Tabela 1 - Brasil: Participação das subcontas na conta financeira - 1999-2002 (\%)

\begin{tabular}{lllll}
\hline Discriminação & $\mathbf{1 9 9 9}$ & $\mathbf{2 0 0 0}$ & $\mathbf{2 0 0 1}$ & $\mathbf{2 0 0 2}$ \\
\hline Conta Financeira & $\mathbf{1 0 0}$ & $\mathbf{1 0 0}$ & $\mathbf{1 0 0}$ & $\mathbf{1 0 0}$ \\
\hline Investimento Direto - Total & 158,34 & 160,07 & 91,24 & 186,33 \\
$\quad$ Investimento Brasileiro Direto & $-9,95$ & $-11,97$ & 8,33 & $-32,78$ \\
$\quad$ Investimento Estrangeiro Direto & 168,29 & 172,04 & 82,91 & 219,11 \\
Investimento em Carteira - Total & 22,39 & 36,50 & 0,28 & $-67,60$ \\
$\quad$ Investimento Brasileiro em Carteira & 1,53 & $-8,90$ & $-2,94$ & $-4,24$ \\
$\quad$ Investimento Estrangeiro em Carteira & 20,86 & 45,40 & 3,22 & $-63,36$ \\
Derivativos - Total & $-0,52$ & $-1,04$ & $-1,74$ & $-4,70$ \\
Outros Investimentos - Total & $-80,21$ & $-95,53$ & 10,22 & $-14,02$ \\
$\quad$ Outros Investimentos Brasileiros & $-25,89$ & $-15,69$ & $-24,31$ & $-42,42$ \\
$\quad$ Outros Investimentos Estrangeiros & $-54,31$ & $-79,84$ & 34,53 & 28,39 \\
\hline
\end{tabular}

Fonte: Elaborada pelas autoras a partir de dados do Banco Central do Brasil.

$6 \quad$ Segundo Cintra e Prates (2005), as taxas de juros nominais ficaram em média em torno de $33 \%$ a.a. entre 1995 e 1998.

7 Tal onda de expansão deve-se também ao período de crescimento econômico dos Estados Unidos entre 1999 e 2002.

MUNHOZ, V. C. V.; GASPAR, L. C. Volatilidade dos fluxos internacionais de capitais... 
Como já foi dito, a fase de liquidez internacional que marcou o início da década chegou ao fim com as crises cambias do primeiro período, principalmente com a crise da Rússia, que colocou fim ao período de abundância do ciclo de liquidez e fez com que iniciasse um período de escassez. Tais crises foram seguidas, ainda, por outras crises como a crise cambial do Brasil em 1999, crise da Turquia em 2001 e crise da Argentina em 2002. Ademais, esse segundo período é marcado também pelos ataques de 11 de setembro e pelos escândalos contábeis nos Estados Unidos. Desse modo, esse conjunto de fatores fez com que houvesse uma retração dos fluxos de capitais para os países emergentes.

Nesse contexto, a fuga de capitais, que ocorreu no Brasil, ao levar a uma grande perda de reservas internacionais fez com que houvesse uma mudança do regime cambial brasileiro, passando de um regime de câmbio administrado para um regime de câmbio flutuante em janeiro de 1999. Com a adoção do novo regime e a elevação do risco-país, o fluxo líquido de recursos em moeda estrangeira para o setor privado se tornou negativo (conta outros investimentos), ou seja, as empresas passaram a reduzir seu endividamento em moeda estrangeira, tendo em vista o aumento do risco cambial; de modo que a forma de financiar o déficit em transações correntes foi a atração de investimento estrangeiro direto e fluxos de capitais externos para a Bovespa e para o sistema financeiro doméstico, sem gerar novos instrumentos e instituições para garantir o financiamento de longo prazo (CINTRA; PRATES, 2005).

Assim, entre meados de 1999 e 2000 é possível notar que, a despeito da volta de recursos para as contas investimento em carteira e investimento direto, o nível de recursos se mantém baixo e os outros investimentos têm uma queda acentuada, oscilando entre superávits e déficits (Tabela 1). Percebe-se, também, a influência dos ataques de 11 de setembro e das crises contábeis americanas, visto que esses elementos levaram a uma retração de recursos na conta investimentos em carteira, gerando um período de escassez de recursos entre maio de 2002 e novembro desse mesmo ano.

Ademais, a partir de meados de abril de 2002, a deterioração das expectativas foi acentuada pelas reduções de risco promovidas pelas agências de classificações de risco e de crédito e pelos analistas de bancos internacionais. Aliado a esse fato, a possibilidade de que Luiz Inácio Lula da Silva ganhasse a eleição presidencial e não cumprisse contratos acentuou ainda mais as expectativas negativas em torno do Brasil. Entretanto, quando ficou claro que Lula honraria as dívidas e os contratos anteriormente estabelecidos, as expectativas melhoraram, levando a uma redução das incertezas decorrentes do processo eleitoral brasileiro associada à queda na aversão ao risco dos investidores internacionais. Assim, no final de 2002, já foi possível notar o início de um novo ciclo de elevada liquidez internacional para as economias emergentes, que voltaram a receber grandes volumes de capital externo. 


\subsection{Período III - 2003 a 2006}

A partir do final de 2002/início de 2003, iniciou-se um novo ciclo de liquidez internacional que persistiu até meados de 2007. Este novo ciclo surgiu depois das reduções das taxas de juros norte-americanas, o que mostra que a dinâmica da expansão ou retração de liquidez continuou sendo fortemente influenciada pelo movimento das taxas de juros do país emissor da moeda-chave do sistema monetário e financeiro internacional. Assim, as baixas taxas de juros dos países centrais levaram a uma expansão das aplicações em títulos de dívida de países emergentes (e entre eles o Brasil), indicando uma maior propensão a riscos e o retorno de posturas financeiras mais descobertas, do tipo Ponzi.

Além dessa fase favorável do ciclo de liquidez internacional, o governo Lula deu continuidade ao processo de abertura financeira com a adoção de algumas medidas, seguindo a mesma estratégia dos governos anteriores. ${ }^{8}$ Uma das medidas que se destaca é a unificação dos mercados de câmbio livre e flutuante e a extinção da Conta de Não-Residentes (CC5) em março de 2005, o que significou uma liberalização adicional das saídas de capitais ao eliminar os limites para que pessoas físicas e jurídicas convertam reais em dólares e os remetam ao exterior. Com essa medida é possível que qualquer residente no país efetue suas remessas diretamente, sem a intermediação das antigas contas de instituições financeiras não-residentes. No mesmo dia da adoção dessa medida, a cobertura cambial às exportações foi flexibilizada, com a ampliação dos prazos de retenção de dólares no exterior pelos exportadores, o que ampliou a conversibilidade da conta corrente do balanço de pagamentos.

Em fevereiro de 2006, outra medida provisória foi adotada, sancionando a concessão de incentivos fiscais aos investidores estrangeiros para aquisição de títulos da dívida pública interna. Tal medida tinha a intenção de reduzir os custos, e dessa forma, estimular o aumento da demanda por títulos públicos internos pelos investidores estrangeiros. Desse modo, juntamente com a dinâmica internacional favorável, a ampliação do grau de abertura financeira iniciada no segundo governo FHC e aprofundada pelo presidente Lula foi um dos condicionantes do desempenho da conta financeira do Balanço de Pagamentos brasileiro entre os anos 2003 e 2006.

Enquanto no período analisado anteriormente as condições de liquidez internacional estavam desfavoráveis e resultaram em uma queda dos investimentos em carteira e outros investimentos; entre 2003 e 2006, com condições internacionais mais favoráveis com relação à liquidez e crescimento, percebemos uma retomada dos fluxos de capitais voluntários, o que permitiu o pagamento das operações de regularização com o FMI, realizadas anteriormente.

8 Conforme Prates (2006), a crescente integração financeira entre o país e o exterior nos últimos quinze anos foi promovida de forma ad hoc, seja mediante resoluções e circulares do Banco Central, seja por meio de Medidas Provisórias.

MUNHOZ, V. C. V.; GASPAR, L. C. Volatilidade dos fluxos internacionais de capitais... 
Não obstante, mesmo sendo um momento de liquidez internacional, houveram momentos de reversão de recursos, como em 2004. Naquele ano, a sinalização de que as taxas de juros norte americanas iriam se elevar provocou uma instabilidade no mercado de títulos de dívida dos países "emergentes", em especial dos títulos dos países da América Latina. Tal fato fez com que os especuladores fossem levados a reestruturar suas carteiras ao menor sinal de risco, o que gerou um movimento de volatilidade (Gráfico 2), ainda que não se possa considerar que houve uma brusca retração da liquidez.

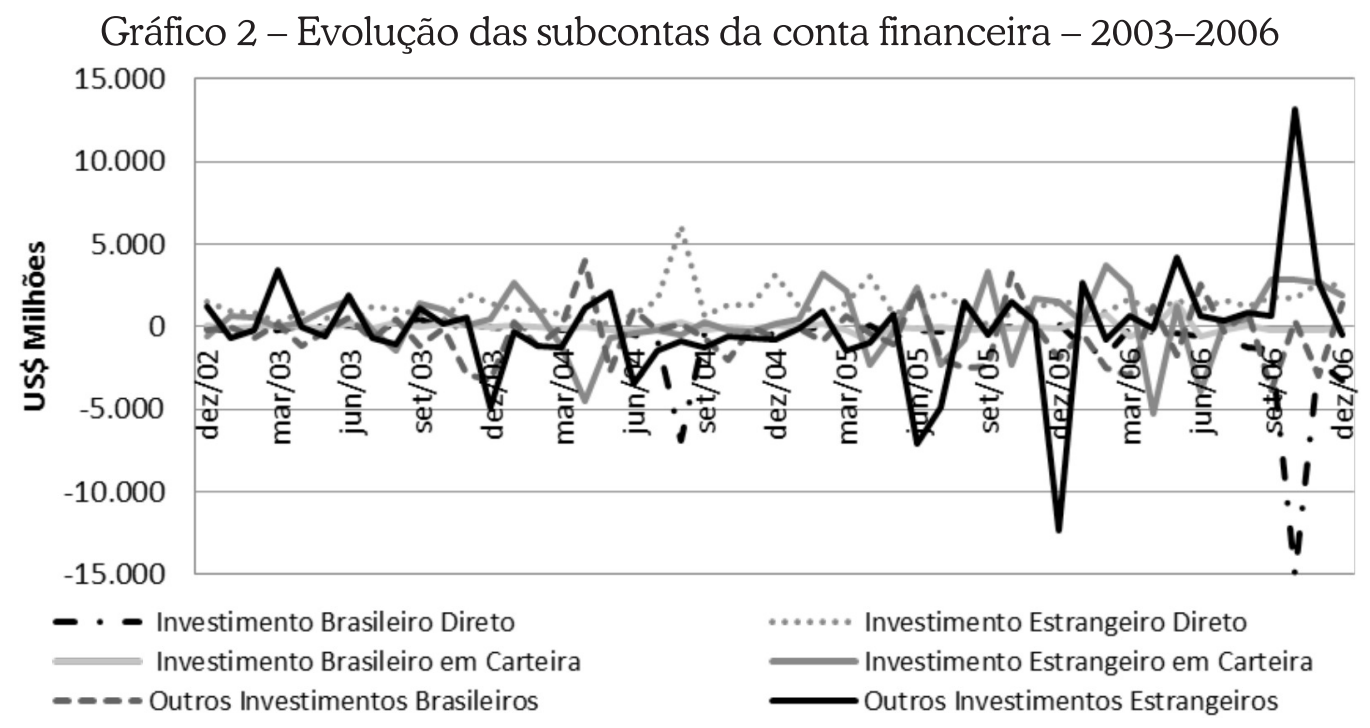

Fonte: Elaborado pelas autoras a partir de dados do Banco Central do Brasil.

Desse modo, percebe-se que mesmo considerando uma melhora nos indicadores de risco e vulnerabilidade dos países emergentes, permanece um forte potencial de volatilidade nas contas financeiras dos Balanços de Pagamentos de tais países, na medida em que estas continuam tendo um forte peso de capitais instáveis e flexíveis.

Ademais, o crescimento dos fluxos de investimentos estrangeiros diretos após 2004 se insere em um movimento de retomada dos fluxos de investimento externo direto para os países periféricos. Contudo, de acordo com Prates (2006), as outras modalidades de fluxos financeiros, investimento em carteira e outros investimentos apresentam um caráter mais instável neste período, de forma que, a partir de 2005, os investimentos em carteira apresentaram fluxos positivos e os outros investimentos obtiveram uma redução no saldo negativo, apresentando ingresso líquido somente em 2006 (Gráfico 2). Além disso, o setor público brasileiro aproveitou as condições de liquidez favoráveis de 2005 para reestruturar sua dívida externa, reduzir o endividamento líquido do setor público e pré-financiar compromissos externos do ano seguinte. 


\subsection{Período IV - 2007 a 2009}

Em 2007, os fluxos de capitais destinados à economia brasileira atingiram o maior valor já registrado pela série do Balanço de Pagamentos do Brasil, atingindo cerca de US\$ 88,4 bilhões e gerando superávit do Balanço de Pagamentos brasileiro no mesmo ano; e só não foi ainda maior devido à eclosão da crise Subprime no final de julho. Um dos principais determinantes desse elevado saldo registrado na conta financeira deve-se ao ciclo de liquidez internacional iniciado em $2003 \mathrm{e}$ ao fato de que a economia brasileira aproveitou ao máximo o boom de capitais externos para os países emergentes.

A interação entre os fatores internos e externos condicionou o desempenho das três principais modalidades de fluxos de capitais, de modo que o crescimento dos fluxos de IED para a economia brasileira após 2004, liderado pela modalidade de participação no capital, insere-se em um movimento de retomada de investimentos pelas empresas transnacionais para os países emergentes Essa retomada deve-se ao dinamismo econômico desses países e pela alta dos preços das commodities e, no caso do Brasil, a absorção do IDE aumentou, sobretudo, devido aos investimentos na atividade de extração de minerais metálicos.

Assim como os fluxos de IED, os outros investimentos estrangeiros (OIE) e os investimentos em carteira tiveram um aumento significativo até meados de 2007, sendo que no caso desses fluxos financeiros os fatores internos ${ }^{9}$ também tiveram sua influência e estimularam tanto a aplicação de não residentes em títulos e ações emitidas por residentes no país ou no exterior, como a contração de créditos comerciais e empréstimos de curto prazo junto aos bancos no exterior.

Destacam-se ainda duas fases distintas na evolução da conta financeira delimitadas pela crise financeira a partir do estouro da bolha especulativa no mercado norte-americano de hipotecas de alto risco. A primeira fase corresponde ao primeiro semestre, quando a trajetória do ingresso líquido dos fluxos financeiros foi ascendente e ancorada no forte crescimento dos investimentos estrangeiros em carteira e dos outros investimentos estrangeiros; revelando uma "euforia" característica dos momentos que antecedem a eclosão das bolhas e agentes menos avessos a correr riscos. No segundo semestre, por sua vez, houve uma reversão dessa trajetória, tornando-a descendente, visto que estas modalidades sofrem alterações em suas trajetórias a qualquer sinal de mudança no cenário econômico internacional ou nas expectativas dos agentes econômicos. Além disso, em momentos de elevada aversão aos riscos e incerteza, a lógica de manada predomina nos mercados financeiros, e os investidores optam por liquidar posições mesmo incorrendo em perdas.

9 Esses fatores internos correspondem à combinação de taxa de juros em patamar ainda elevado com a tendência de apreciação cambial e também ao boom de ofertas públicas iniciais de ações.

MUNHOZ, V. C. V.; GASPAR, L. C. Volatilidade dos fluxos internacionais de capitais... 
Já em 2008, a conta financeira apresentou um superávit de US\$28.296,50 milhões. Um conjunto de fatores externos e internos contribuiu para atenuar a retração dos fluxos de capitais estrangeiros para o país, no contexto de aprofundamento da crise financeira internacional. Um desses fatores foi o desempenho excepcional do IED, que atingiu valor recorde de cerca de US $\$ 45$ bilhões, estimulados pelas perspectivas de lucro nos setores produtores de commodities e nas indústrias baseadas em recursos naturais, tendo em vista a trajetória altista dos preços desses produtos até meados do ano de 2008 ; bem como pelo maior dinamismo do mercado interno.

Ademais, a alta dos preços das commodities e a elevação da classificação do risco de crédito soberano do Brasil para "grau de investimento" pelas agências internacionais de rating (primeiro pela Standard $\mathcal{E}$ Poors e, depois, pela Fitch), favoreceram os investimentos de portfólio em ações. Verifica-se, também, que o diferencial entre os juros interno e externo estimulou as aplicações em títulos públicos de renda fixa no país e as captações de empréstimos de curto prazo no exterior.

No primeiro semestre de 2008, apesar das variações mensais, os fluxos de recursos se mantêm positivos, enquanto no segundo semestre percebe-se que o efeito contágio da crise afeta principalmente os investimentos em carteira e os outros investimentos; ao passo que os investimentos diretos, em função do comportamento menos volátil e mais inercial, continuam apresentando superávit. De acordo com Fundap (2009), o forte aumento da aversão ao risco após a falência do banco de investimento Lehman Brothers, em meados de setembro de 2008, converteu a crise financeira internacional em um fenômeno sistêmico; de modo que o movimento de desalavancagem global e de fuga para a qualidade contaminou os fluxos financeiros por meio de dois canais de transmissão: a) a liquidação dos investimentos em portfólio no mercado financeiro doméstico e; b) a contração dos créditos externos, incluindo os direcionados ao comércio exterior.

Além disso, com relação aos investimentos estrangeiros em carteira, o tempo e a intensidade do efeito contágio da crise não foram homogêneos, sendo que os investimentos em ações no país foram os primeiros a serem contaminados, tornando-se negativos a partir de julho e registrando o seu maior valor negativo em outubro (US\$ 6.066 milhões), quando o aumento da preferência pela liquidez e a necessidade de cobrir perdas em outros mercados resultaram em intenso resgate de aplicações dos investidores estrangeiros na Bovespa.

Com relação a 2009, temos além da melhora no ingresso líquido dos fluxos de capitais estrangeiros, uma mudança na composição desse ingresso. Enquanto, no ano anterior os IED corresponderam à maior parte dos recursos, em 2009 essa participação se reduziu, de modo que os investimentos estrangeiros em carteira passaram a ter a maior participação na Conta Financeira, conforme dados da Tabela 2. 
Tabela 2 - Brasil: Participação das subcontas na conta financeira - 2007-2009 (\%)

\begin{tabular}{llll}
\hline Discriminação & $\mathbf{2 0 0 7}$ & $\mathbf{2 0 0 8}$ & $\mathbf{2 0 0 9}$ \\
\hline Conta financeira & $\mathbf{1 0 0}$ & $\mathbf{1 0 0}$ & $\mathbf{1 0 0}$ \\
\hline Investimento Direto - Total & 31,15 & 86,94 & 51,35 \\
$\quad$ Investimento Brasileiro Direto & $-8,00$ & $-72,30$ & 14,37 \\
$\quad$ Investimento Estrangeiro Direto & 39,15 & 159,24 & 36,98 \\
Investimento em Carteira - Total & 54,78 & 4,00 & 71,66 \\
$\quad$ Investimento Brasileiro em Carteira & 0,32 & 6,71 & 5,88 \\
Investimento Estrangeiro em Carteira & 54,46 & $-2,71$ & 65,78 \\
Derivativos - Total & $-0,80$ & $-1,10$ & 0,22 \\
Outros Investimentos - Total & 14,87 & 10,16 & $-23,23$ \\
$\quad$ Outros Investimentos Brasileiros & $-21,00$ & $-18,62$ & $-43,29$ \\
Outros Investimentos Estrangeiros & 35,87 & 28,78 & 20,06 \\
\hline
\end{tabular}

Fonte: Elaborada pelas autoras a partir de dados do Banco Central do Brasil.

Esse movimento de retorno de capitais com caráter mais volátil deve-se a um novo movimento mais geral de retorno desses fluxos para as economias "emergentes", ao longo de 2009, em um contexto de melhoria nas condições dos mercados financeiros internacionais. Todavia, um conjunto de características específicas da economia brasileira contribuiu para fomentar a volta desses recursos. Por um lado, os investimentos em ações foram estimulados pelas perspectivas de alta dos preços desses papéis, associadas à forte desvalorização no último trimestre de 2008 e, em um momento posterior, à recuperação dos preços das commodities e do amplo mercado de consumo doméstico. Por outro lado, as captações externas, assim como as aplicações em títulos públicos de renda fixa no país, foram estimuladas pela manutenção do elevado diferencial entre os juros interno e externo, em um contexto de taxas de juros historicamente baixas nos países centrais.

Outro fator que influenciou o forte crescimento do ingresso de recursos externos foi a menor saída de capitais brasileiros para o exterior. Isso se deu devido ao retorno líquido de investimentos brasileiros (principalmente diretos e, em menor medida, investimentos em carteira), em um contexto de baixas oportunidades de lucro nos países avançados; além de perspectivas favoráveis em relação à economia brasileira. Todavia, a saída de recursos pela subconta outros investimentos brasileiros (OIB) registrou um forte crescimento em função de três fatores: a) aumento dos ativos dos bancos brasileiros no exterior; b) maior número de empresas exportadoras que utilizou a prerrogativa de manter suas receitas no exterior, registradas no Balanço de Pagamentos como crédito comercial ativo; e em menor medida, c) créditos comerciais ativos concedidos por residentes, em razão de uma 
mudança de ordem metodológica efetuada pelo Banco Central do Brasil, passaram a ser contabilizados nessa conta. ${ }^{10}$

Com base nesta análise, a próxima seção procura analisar o mercado de crédito brasileiro para o mesmo período, de forma a tentar mostrar a influência dos movimentos dos fluxos de capitais voláteis na oferta de crédito na economia doméstica.

\section{Análise da Oferta de Crédito no Brasil}

Os dados correspondentes à oferta de crédito na economia doméstica utilizados neste trabalho são de dois tipos: o primeiro tipo engloba dados do balancete analítico dos bancos criadores de moeda, que consolida as contas de todas as instituições financeiras monetárias (bancos múltiplos com carteira comercial, bancos comerciais, Banco do Brasil, Caixa Econômica Federal e Caixas econômicas estaduais que existiram até novembro de 1998) e o segundo tipo se refere aos dados de instituições financeiras específicas a fim de melhor exemplificar as análises feitas do primeiro tipo. Todos os dados foram obtidos junto ao sistema de contas nacionais do Banco Central brasileiro e de suas informações bancárias contábeis, estando em milhões de reais.

As contas analíticas dos bancos criadores de moeda se referem a um conjunto de séries agrupadas em contas do ativo e do passivo, conforme o quadro 1. Para os fins deste estudo, serão analisadas as participações de determinadas contas no total do ativo e do passivo dos bancos criadores de moeda, de modo que fique claro que em momentos de crise há uma tendência clara de aumento da liquidez dos bancos e diminuição da oferta de crédito, mesmo sendo o momento em que as empresas e famílias mais necessitam de recursos para honrarem seus compromissos.

Quadro 1 - Brasil: contas analíticas dos bancos criadores de moeda

\begin{tabular}{|ll|}
\hline Ativo & Passivo \\
\hline Reservas & Depósitos à vista \\
Títulos do Banco Central & Depósitos a prazo, poupança e outros \\
Ativos externos & Instrumentos do mercado monetário \\
Créditos ao governo federal & Depósitos especiais \\
Créditos aos governos estaduais e municipais & Passivos externos \\
& Passivos externos de longo prazo \\
Crédito a empresas públicas não financeiras & Depósitos do governo federal \\
& Créditos da Autoridade Monetária \\
Créditos ao setor privado & Obrigações com outras instituições bancárias \\
Créditos a outras instituições bancárias & Obrigações com outras instituições financei- \\
& ras não bancárias \\
Créditos a instituições financeiras não bancá- & Contas de capital \\
rias & Outros itens \\
\hline
\end{tabular}

Fonte: Elaborado pelas autoras a partir de informações do Banco Central do Brasil.

10 Anteriormente, esses créditos eram incluídos na conta outros investimentos estrangeiros com o sinal contrário, como uma redução do passivo de residentes. 
As reservas correspondem às disponibilidades do sistema bancário que se encontram no ativo das instituições ou depositadas no Banco Central sob as formas de caixa, reservas livres, reservas compulsórias em espécie, depósitos voluntários e compulsórios do Sistema Brasileiro de Poupança e Empréstimo (SBPE) e financiamentos concedidos ao Banco Central em operações compromissadas com títulos públicos. Em momentos de maior instabilidade a tendência é que a participação das reservas no total do ativo aumente. Os depósitos à vista correspondem à uma rubrica do passivo referente aos depósitos dos governos estaduais, municipais, das empresas estatais das três esferas de governo e do setor privado, bem como tributos estaduais e municipais. Representam os recursos mais líquidos que os bancos dispõem, de modo que quanto mais estável a economia se encontra, menor a participação desse tipo de recursos no total do passivo. Os instrumentos do mercado monetário correspondem às captações de recursos através da colocação de letras de câmbio, imobiliárias e hipotecárias, bem como financiamentos tomados em operações compromissadas com títulos dos governos estaduais e municipais, empresas públicas não financeiras e setor privado. No caso dos bancos que atuam no Brasil, percebe-se que eles tendem a alocar seus recursos nesse tipo de aplicações tendo em vista a segurança, rentabilidade e liquidez que essas aplicações oferecem. De modo semelhante às reservas, quanto maior a instabilidade na economia, maior a tendência de aplicações em instrumentos do mercado monetário.

A análise dos dados do sistema bancário brasileiro será dividida em dois subperíodos (1995-2002 e 2003-2009) apenas para melhor visualização nos gráficos, visto que o recorte dos dados é mensal. Ademais, os dados das contas analíticas dos bancos criadores de moeda referentes ao ano de 1995 só estão disponíveis para o mês de dezembro.

Com relação aos dados de bancos específicos temos que os mesmos foram separados de acordo com o seu controle patrimonial. Os bancos analisados seguem abaixo: a) Bancos públicos: Banco do Brasil, Caixa Econômica Federal e Banco do Nordeste; b) Bancos privados nacionais: Bradesco, Itaú e Unibanco ${ }^{11}$; c) Bancos privados estrangeiros: HSBC, Santander e ABN Amro (Real). ${ }^{12}$

A primeira fase analisada, entre 1995-2002, engloba a ocorrência e consequências de vários eventos importantes: inicia-se com a implementação do Plano Real; atravessa as crises cambiais do final da década de 1990 e termina com os ataques de 11 de setembro e a crise da Argentina. É um período no qual se processam importantes mudanças patrimoniais no sistema bancário brasileiro, já que ocorre a entrada dos bancos estrangeiros, além da privatização dos bancos estaduais. Ade-

11 Para julho de 2007, julho de 2009 e dezembro de 2009 os dados do Unibanco se referem aos dados do Itaú-Unibanco.

12 Os dados referentes ao banco ABN Amro Real só estão disponíveis até 2008, visto que em 2009 o banco passou a ser controlado pelo banco Santander.

MUNHOZ, V. C. V.; GASPAR, L. C. Volatilidade dos fluxos internacionais de capitais... 
mais, é um período de intensa instabilidade financeira internacional envolvendo as crises cambiais.

É possível notar, no início desse período (1995-2002), que as taxas de juros norte-americanas estão baixas e o câmbio sobrevalorizado, o que facilita a entrada de recursos estrangeiros para o Brasil, sobretudo no quarto trimestre de 1996. Há ainda um movimento de redução dos juros domésticos e percebe-se que há uma dominação dos títulos públicos pré-fixados. Ademais, associado a este movimento ocorreu a implementação do Plano Real, de modo que os bancos, em um primeiro momento, expandiram a oferta de crédito e se tornaram menos seletivos a fim de compensar as perdas das receitas inflacionárias. Os bancos adotaram, assim, posturas mais arriscadas e aumentaram o seu grau de alavancagem, ou seja, passaram a se comportar mais como agentes especulativos e Ponzi, seguindo a tipologia de Minsky (1986).

Já entre o final de 1997 e 1999, pode-se observar que se trata de um momento de baixa liquidez internacional, com fugas de capitais das economias periféricas, desvalorização do câmbio e crescimento dos juros domésticos; efeitos derivados das crises ocorridas nesses anos. A resposta dos bancos brasileiros (tanto públicos, como privados nacionais ou estrangeiros), nesse contexto de maior incerteza e instabilidade, foi aumentar a participação em seus portfólios dos títulos públicos pós-fixados pela taxa de juros em detrimento das operações de crédito.

Assim, a partir de meados de 1997, percebe-se a queda acentuada da participação das operações de crédito no total do ativo, de modo que se em dezembro de 1995 essa participação atingia 73,42\%, em 1997 fica em torno dos 61\%, chegando até mesmo a 53,01\% em dezembro desse mesmo ano. A partir daí, essa relação tende a cair ainda mais, confirmando que em momentos de instabilidade e incerteza os agentes econômicos se tornam mais cautelosos, principalmente os bancos, que reagem restringindo a oferta de crédito, aumentando as aplicações em títulos públicos e a disponibilidade de reservas. Ademais, o aumento das taxas de juros na tentativa de conter as pressões inflacionárias em decorrência da expansão do crédito acentuou ainda mais a inadimplência dos agentes.

Diante dessa situação, os bancos aumentaram a sua preferência pela liquidez (PLB) e aversão ao risco. Isto pode ser visto por meio da aplicação de um índice de PLB dos Bancos, calculado da seguinte forma:

$$
\mathrm{PLB}=\frac{\text { Depósitos à vista }}{\text { Operações de crédito }}
$$

A ideia embutida na aplicação deste índice é mostrar como o sistema bancário aloca seus recursos entre ativos de maior ou menor liquidez levando em conta o grau de liquidez do seu passivo. Desta aplicação, obtivemos o resultado plotado no Gráfico 3, que mostra que enquanto no final de 1995 o índice de preferência pela liquidez atingiu 5,87\%, no final de 1999 já ultrapassava os 12,5\%. 
Gráfico 3 - Brasil: preferência pela liquidez dos bancos - 1995-2002

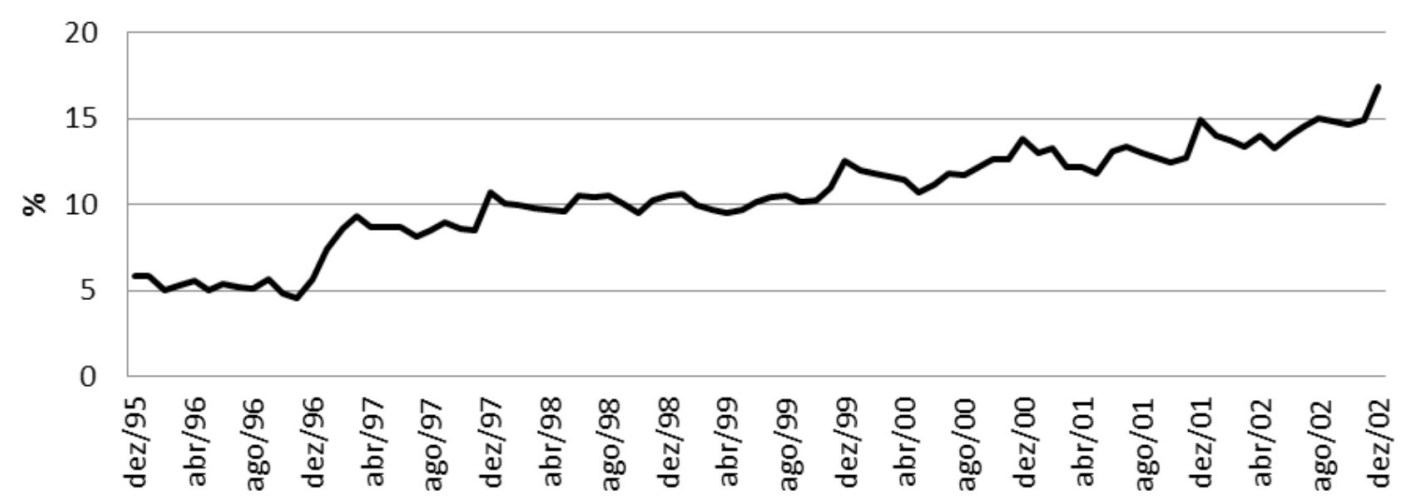

Fonte: Elaborado pelas autoras a partir de dados do Banco Central do Brasil.

Entre 2000 e 2002 percebe-se um período de ajuste e transição: ainda não existe uma total estabilidade internacional, dados o ataque de 11 de setembro, a crise da Argentina e a eleição presidencial no Brasil. Os agentes permanecem cautelosos e os bancos continuam a restringir a oferta de crédito e aumentar suas reservas. Além disso, a preferência pela liquidez dos bancos continua a aumentar, de modo que em dezembro de 2002 ela representa 16,83\%, o maior índice observado nessa fase.

Com relação ao comportamento de alguns dos bancos privados nacionais (Bradesco e Unibanco), eles traçam um sentido inverso ao percorrido durante as crises ocorridas anteriormente, de forma que a importância relativa das operações de crédito no total do ativo aumenta (Tabela 3). Entretanto, os bancos estrangeiros se mostram mais avessos aos riscos e apresentam uma diminuição da participação das operações de crédito no seu portfólio. 


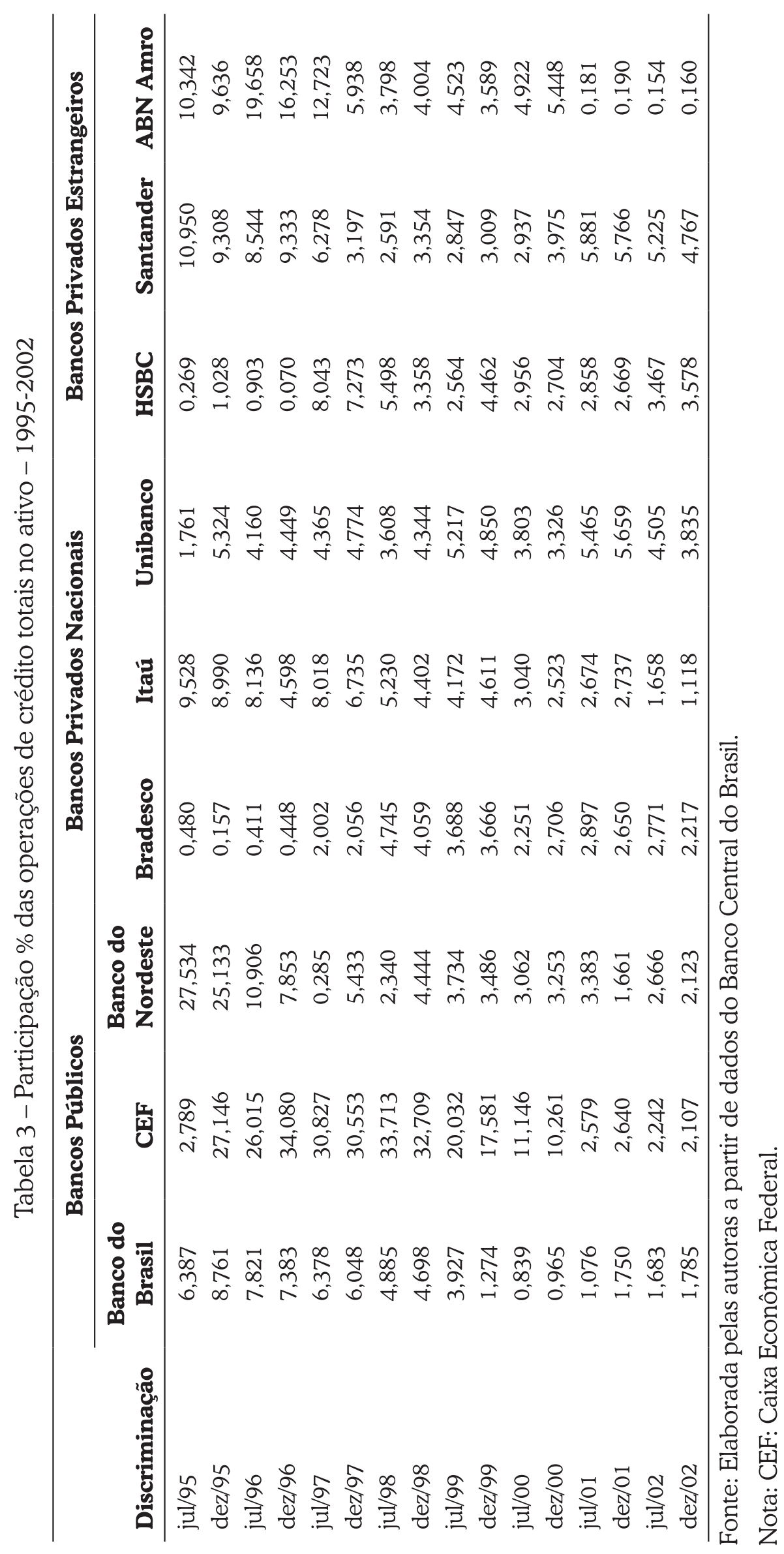


A exceção dentre os bancos privados estrangeiros é o HSBC (participação em julho de 1995 de $0,269 \%$, e em dezembro de 2002 de 3,578\%). Isso se deve ao fato de que em 1997 ele passou a ter controle sobre o Banco Bamerindus e, dessa forma, além do aumento do seu montante de crédito ofertado, seu ativo também aumentou de modo significativo.

A preferência pela liquidez entre 1995 e 2002 também aumentou de modo significativo, principalmente nos anos das crises da Ásia, Rússia e Brasil. Isso nos leva a pensar que mesmo que a volatilidade dos fluxos de capitais não tenha uma relação direta com a oferta de crédito no Brasil, ela decerto influencia o comportamento dos bancos. Essa intensa volatilidade traz insegurança e instabilidade para os bancos, que são os primeiros a responder a essa insegurança, seja reduzindo a oferta de crédito, aumentando as aplicações em títulos públicos, ou aumentando suas reservas, conforme Gráfico 4.

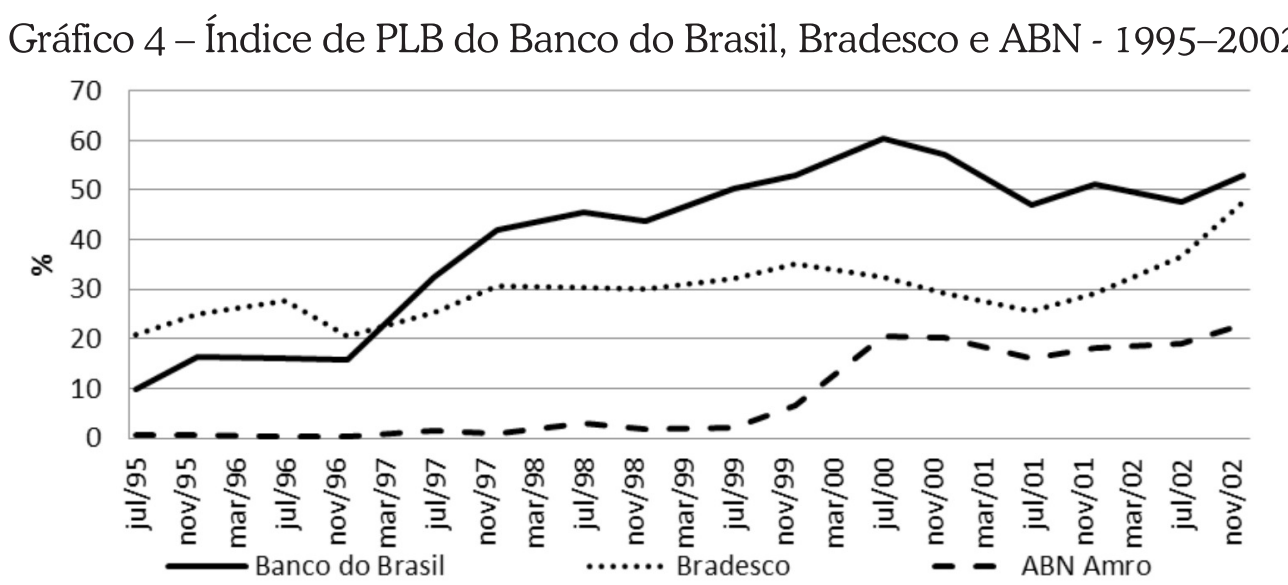

Fonte: Elaborado pelas autoras a partir de dados do Banco Central do Brasil.

A despeito da estranha impressão de que a preferência pela liquidez de um banco público seja maior que a de um banco privado, o que deve ser levado em consideração é que a quantidade de depósitos à vista do Banco do Brasil cresceu a uma taxa bem superior a quantidade de crédito ofertada no período; ou seja, enquanto que os depósitos à vista cresceram a uma taxa de 13,73\% de julho de 1995 a dezembro de 2002, as operações de crédito cresceram apenas $2,47 \%$ no mesmo período. Além disso, mesmo com uma quantidade de depósitos bem superior a do Bradesco, o Banco do Brasil possui uma quantidade de operações de crédito semelhante a esse banco. Outra consideração que deve ser feita é com relação ao ABN Amro, o aumento abrupto da sua preferência pela liquidez em meados de 1999 deve-se às aquisições desse banco no período: Banco Real S.A. (1998), Bandepe (1998), Paraiban (2001) e Sudameris (2003). Desse modo, houve um aumento significativo dos depósitos à vista e, em menor quantidade, das operações de crédito. 
Ainda no que se refere ao aumento da preferência pela liquidez, podemos perceber também um aumento de aplicações em títulos e valores mobiliários (TVM) nos momentos de maior instabilidade. Nessa primeira fase analisada, esse aumento da participação dos títulos como uma forma mais segura de manter os seus recursos se dá principalmente entre 1997 e 1999, anos já citados exaustivamente como momentos de instabilidade. Após esses anos críticos, há uma redução nessa participação, todavia, termina-se essa fase com uma participação dos títulos no total do ativo maior do que o ano inicial, pelo menos na maior parte dos bancos analisados (Tabela 4). 


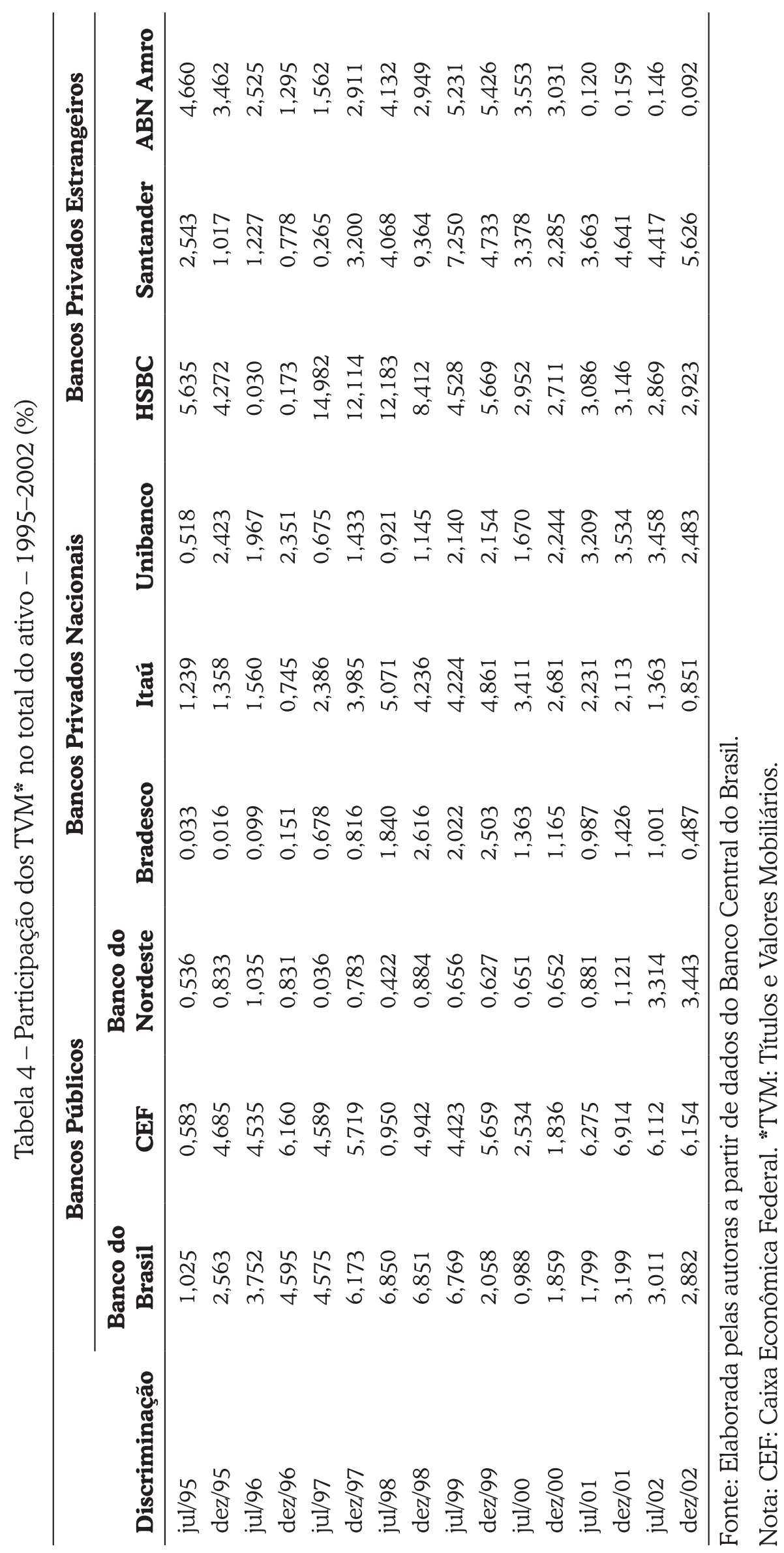

MUNHOZ, V. C. V.; GASPAR, L. C. Volatilidade dos fluxos internacionais de capitais... 
Paralelamente ao aumento da participação dos títulos e valores mobiliários sobre o total dos ativos, nota-se, também, que há uma queda nas aplicações interfinanceiras por parte dos bancos. Estas correspondem às reservas secundárias, que caíram diante da elevação da taxa Selic, quando o Banco Central reagiu ao efeito contágio da crise asiática e russa.

No segundo período analisado, entre 2003 e 2009, diferentemente do anterior, não se notam crises financeiras internacionais significativas e a crise do sistema financeiro norte americano só viria a se manifestar no final de 2007, e a se aprofundar no segundo semestre de 2008. É uma fase de estabilidade e de forte liquidez internacional. Ademais, é uma fase em que o câmbio está valorizado e em que os juros domésticos passam por reduções paulatinas. Nota-se, também, nesse período, o retorno da capacidade do governo de emitir títulos públicos pré-fixados perdida em meados de 1998.

Em um ambiente mais favorável e estável, como esse, os agentes voltam a ter um comportamento menos coberto e passam a arriscar mais. No que se refere aos bancos isso não é diferente. O crédito ofertado na economia aumenta de modo significativo, saindo do piso de $22 \%$ do Produto Interno Bruto (PIB) para atingir 45,2\% do PIB em novembro de 2009 (Gráfico 5). Ademais, mesmo no período da crise de subprime, a relação crédito/PIB não diminui de modo significativo, ou seja, mesmo com os efeitos negativos da crise sobre o mercado de crédito doméstico (que serão detalhados mais a frente) os bancos não deixaram de ofertar crédito. Na verdade o que acontece é que a oferta de crédito cresce a uma taxa menor, não seguindo o mesmo ritmo dos momentos favoráveis do ciclo econômico.

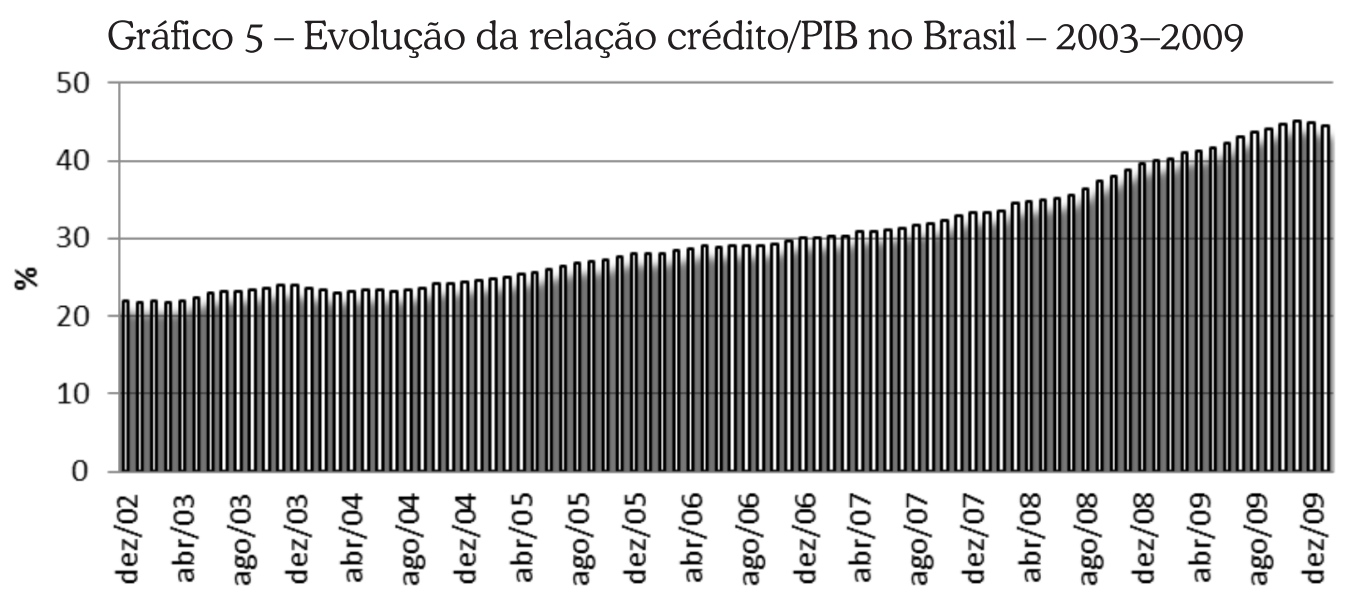

Fonte: Elaborado pelas autoras a partir de dados do Banco Central do Brasil.

As perspectivas favoráveis de uma redução gradual das taxas de juros de curto prazo no final de 2005 nesse ambiente macroeconômico de aceleração do crescimento do PIB e da renda, além da estabilidade internacional estimularam 
as instituições financeiras a expandirem o seu mercado, ampliando a variedade de produtos destinados ao crédito pessoal. Assim, é comum notar nesse período alianças entre bancos e redes de loja de varejo, o que faz com que a oferta de crédito se eleve ainda mais.

Após essa fase de euforia com relação à oferta de crédito e a dinâmica internacional favorável, principalmente no que se refere à liquidez internacional, houve uma reversão do ciclo econômico. Essa reversão se deu com a falência do banco de investimentos Lehman Brothers em setembro de 2008, que transformou a crise financeira internacional já iniciada em meados de 2007, no mercado norteamericano de hipotecas de alto risco, em uma crise sistêmica de proporções globais. Diante disso, houve um aumento da preferência pela liquidez e da aversão ao risco, o que fez com que se desencadeasse um movimento de fuga de capitais em busca de qualidade de investimento e também a interrupção das linhas externas de crédito comercial. Com o aprofundamento dessa crise, percebe-se ainda uma realocação dos portfólios das filiais dos bancos estrangeiros, que respondendo às determinações das matrizes aumentaram a preferência pela liquidez e retraíram as operações de crédito.

Desse modo, duas características do sistema bancário brasileiro precisam ser levadas em conta quando se observa o impacto desta crise no mercado de crédito doméstico. Primeiro, a dinâmica concorrencial no sistema bancário brasileiro nos momentos de auge do ciclo econômico estimulam os bancos a subestimarem os riscos inerentes às atividades bancárias; o que os leva a adotar posturas mais alavancadas e descobertas, características do agente Ponzi, conforme construção teórica de Minsky (1986). Quando há a reversão do ciclo, os efeitos desestabilizadores são potencializados por essas posturas e são disseminados por toda a economia. A segunda característica se refere ao fato de que nesse momento de reversão, os bancos adotam um conservadorismo excessivo, ou seja, retraem a oferta de crédito quase que imediatamente, o que contribui para a desaceleração da atividade econômica e amplificação do quadro de crise. Ademais, os bancos aplicam parte dos recursos que seriam destinados a empréstimos e financiamentos em títulos públicos que garantem liquidez, rentabilidade e segurança. Sobre esta postura dos bancos, Prates e Biancareli (2009) apontam que, historicamente, os bancos brasileiros e estrangeiros priorizaram as aplicações em títulos públicos em detrimento da concessão de crédito. Assim, mesmo com a expansão do crédito a partir de 2003, não houve uma transformação estrutural no perfil de atuação do sistema financeiro brasileiro. Na verdade, para os autores supracitados houve foi uma alteração no mix de atividades mais rentáveis para os bancos. Isto revela a busca de maior rentabilidade em momentos de estabilidade vis-à-vis o aumento da preferência pela liquidez em momentos de instabilidade. 
O Gráfico 6 tenta captar algumas dessas considerações. Foram considerados nesta análise gráfica a participação do componente "Títulos e Valores Mobiliários" no total do ativo de cada banco, sendo que a análise é feita apenas para os bancos privados nacionais e estrangeiros, sendo que o banco ABN Amro não foi incluído devido à sua incorporação ao Santander em 2009. Nota-se que no período da crise do subprime, desde o seu início em meados de 2007 até o início de 2009, há uma elevação significativa na participação dos títulos e valores mobiliários no total do ativo do bancos. Conforme dito anteriormente, a presença no Brasil de títulos públicos líquidos, rentáveis e de baixo risco permite uma rápida mudança na composição das carteiras dos bancos. Assim, em momentos de crise e instabilidade, os bancos rapidamente optam por esse tipo de aplicações a fim de evitar grandes perdas e garantir a sua lucratividade no período, vis-à-vis a diminuição da oferta de crédito.

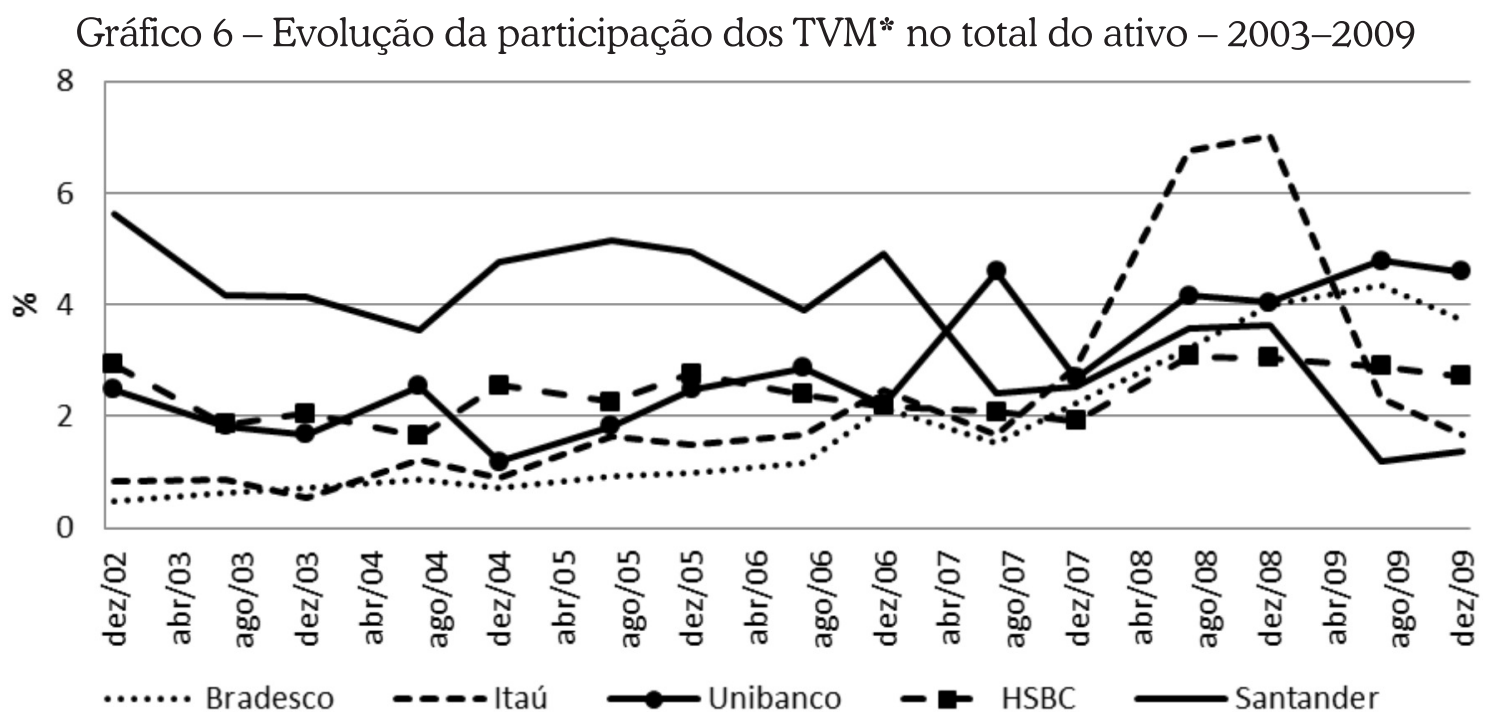

Fonte: Elaborado pelas autoras a partir de dados do Banco Central do Brasil.

Nota: *TVM: Títulos e Valores Mobiliários.

Nesse sentido, fica claro que uma crise de proporções internacionais como essa, que leva a uma intensa fuga de capitais dos países que não emitem moeda forte tem impactos sobre o mercado de crédito doméstico mediante canais de transmissão indiretos. A deterioração das condições financeiras nas economias centrais contribui para um menor dinamismo das economias periféricas e de seus mercados de capitais, como ocorreu no Brasil. Para cobrir as perdas em seus países de origem, os investidores estrangeiros se desfizeram de suas posições no mercado de capitais domésticos, de modo que a captação de novos recursos pelas empresas brasileiras através de ofertas públicas iniciais no mercado de capitais nacional foi restringida (a maior parte dos investidores é estrangeira). Ademais, também houve uma retração da captação direta das empresas no mer- 
cado internacional mediante empréstimos dos bancos ou emissão de títulos e dos empréstimos bancários concedidos às empresas no país com base em Adiantamentos dos Contratos de Câmbio (ACC's), repasses externos e financiamento às exportações.

Ainda sobre o período 2003-2009 cabe ressaltar que no contexto pós-crise as operações de crédito voltam a crescer, com uma reativação da oferta de crédito em todas as categorias da atividade econômica, embora tenha havido uma redução do crédito à pessoa física durante a crise. Assim, em virtude do maior crescimento das operações de crédito terem se dado no segmento de recursos livres, observa-se, a partir do Gráfico 7, que o crédito a pessoas físicas contribuiu aproximadamente $32 \%$ para o crescimento do total de crédito ao setor privado, bem a frente do crédito à indústria (24\%) e ao setor de serviços (17\%).

Gráfico 7 - Crédito por atividade econômica como \% do crédito total do sistema financeiro - Setor Privado - média do período 2003 a 2009

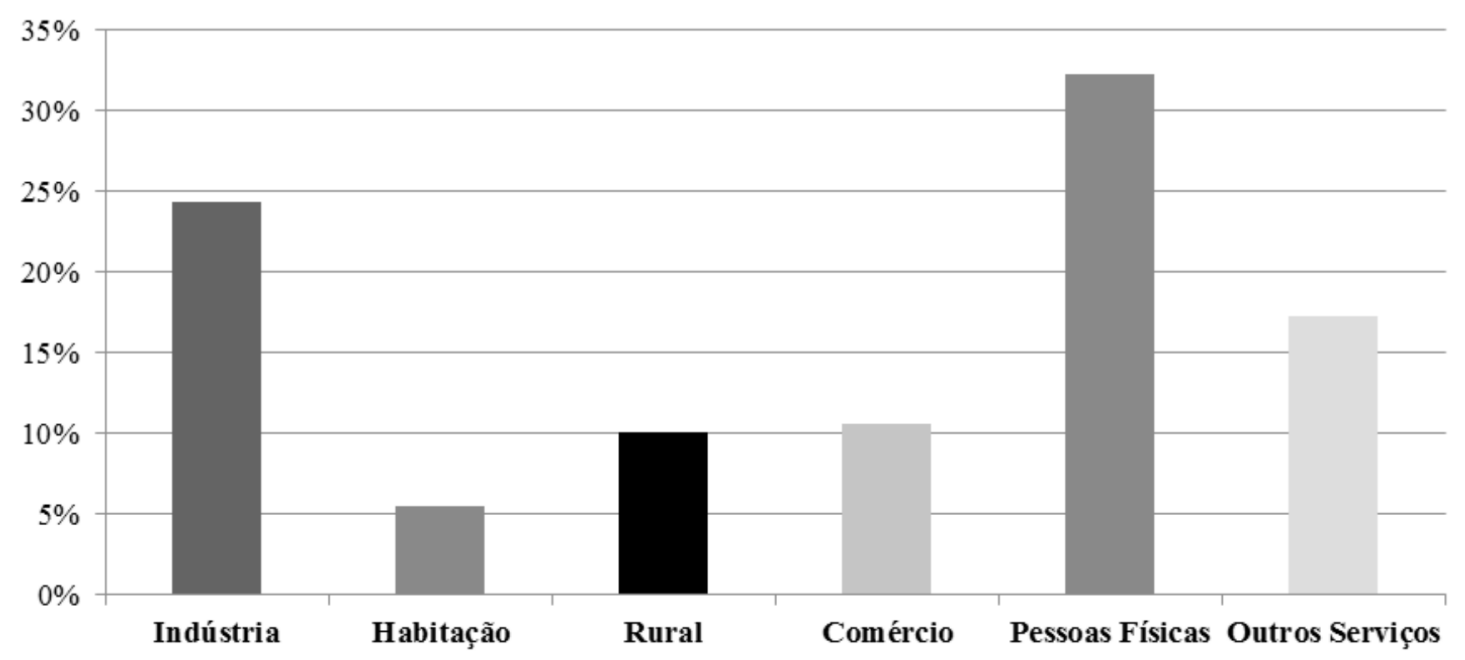

Fonte: Elaborado pelas autoras a partir de dados do Banco Central do Brasil.

Mais especificamente a partir de 2003, os bancos expandem o crédito pessoal e, a partir de 2004, introduzem o crédito consignado ${ }^{13}$ (uma inovação financeira que teve um papel fundamental na evolução do crédito à pessoas físicas). Esta se torna, a partir daí, uma importante modalidade para expansão do crédito no Brasil.

Com efeito, a forte ampliação do crédito a pessoas físicas coincide com o período de grande entrada de capitais estrangeiros no País, gerando uma tendência crescente de valorização cambial, o que levou o Banco Central (BCB) a adotar

13 O crédito consignado, com desconto em folha de pagamento, para trabalhadores ativos e inativos foi viabilizado pela Lei 10820 de 17 de dezembro de 2003 (CINTRA, 2006). Segundo Prates e Biancareli (2009) trata-se de uma inovação patrocinada pelo governo, com intuito de favorecer a redução do custo dos empréstimos. 
mais tarde - no final de 2010 - uma série de medidas $^{14}$ de natureza macroprudencial, especificamente no mercado de crédito, com o intuito de aperfeiçoar os instrumentos de regulação existentes e manter a estabilidade do sistema financeiro nacional.

\section{A Relação entre Fluxos de Capitais e Oferta de Crédito}

Diante de todos esses elementos, percebemos que o Brasil, por estar em uma posição periférica na economia internacional, está sujeito a fugas de capitais e ataques especulativos que deixam a economia vulnerável e instável, sujeitas à ocorrência de momentos de contexto internacional não favorável. Assim, quando a economia internacional não está muito bem e passa por momentos de crise, um dos primeiros elementos a sofrer as consequências é a conta financeira brasileira. Como foi visto, tal conta é formada em grande parte por capitais voláteis, sujeitos à reversão ao menor sinal de risco ou mudança nas expectativas dos agentes.

Os investidores estrangeiros sempre que desconfiam da capacidade do Brasil (e também de outros países periféricos) em honrar seus compromissos retiram seus recursos dessas economias. Por conseguinte, geram-se efeitos no saldo da conta financeira, bem como efeitos nas expectativas dos agentes econômicos, principalmente nas dos bancos. Desse modo, a relação entre os fluxos de capitais voláteis que se destinam à economia brasileira e a oferta de crédito na economia doméstica não é direta, mas sim devido aos impactos que essa volatilidade tem sobre a preferência pela liquidez dos agentes bancários (Gráfico 8).

$14 \quad$ Uma medida que ganhou destaque foi adotada no dia 3 de dezembro de 2010, quando o BCB anunciou a elevação de $8 \%$ para 12\% (Circular n. 3.514) do adicional do compulsório sobre depósitos à vista e a prazo, em vigor desde 2002, e de $11,0 \%$ para 16,5\% (Circular n. 3.515) do capital mínimo para operações de crédito a pessoas físicas com prazo superior a 24 meses. 


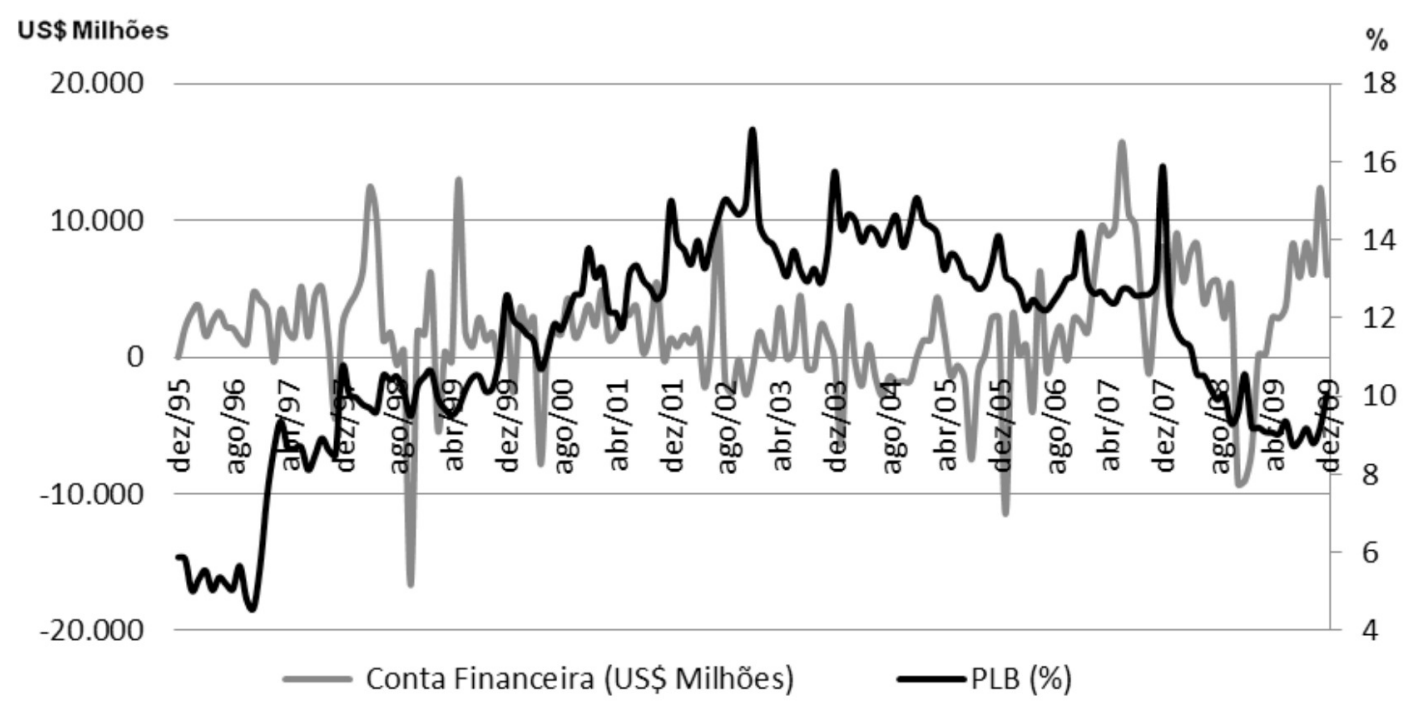

Fonte: Elaborado pelas autoras a partir de dados do Banco Central do Brasil.

Sempre que ocorre uma crise internacional e os bancos desconfiam que podem perder recursos, ou que estão em uma posição tão alavancada que não são capazes de sustentá-la, aumentam sua preferência pela liquidez e fazem uma realocação no seu portfólio; de modo que o crédito se reduz imediatamente - conforme mostrado pela experiência histórica, e há um aumento pela preferência de ativos mais líquidos e que lhe conferem maior segurança. Ao reduzir o crédito, o crescimento econômico também pode se reduzir, levando a um desaquecimento da economia, já que é o crédito que possibilita que novos investimentos possam ser efetivados.

Dessa maneira, é evidente que nos períodos mais críticos (crise da Ásia em 1997, da Rússia em 1998, do Brasil em 1999, ataques de 11 de setembro em 2001, crise da Argentina em 2002 e crise do subprime em 2007/2008) a conta financeira brasileira apresentou quedas acentuadas, dadas as fugas de capitais que ocorreram nesses períodos. Isso se explica pelo fato da moeda doméstica não ser uma moeda conversível, como a dos países centrais. Os investidores estrangeiros retiram seus recursos dos países que não emitem moeda forte em direção às aplicações mais seguras, a fuga por qualidade. Nestes momentos, nem o alto diferencial de juros é capaz de sustentar o "apetite" dos investidores. Ao deixarem de investir no Brasil, acentua-se a instabilidade e a vulnerabilidade econômica do País. Nesse contexto, os bancos ao perceberem que suas expectativas otimistas não se concretizaram buscaram se proteger dos riscos da atividade bancária, optando por adotar posturas mais cobertas, ou hedge, nos termos de Minsky (1986). É nesse ponto que a relação entre as duas variáveis analisadas nesse estudo se torna mais evidente. 
A partir do momento em que ocorrem as fugas de capitais e os bancos adotam posturas mais conservadoras, há um aumento da preferência pela liquidez dos bancos, ou seja, a oferta de crédito na economia doméstica se reduz. É este, portanto, o impacto deletério que os fluxos de capitais voláteis geram sobre a oferta de crédito no Brasil.

\section{Considerações Finais}

A transição no Brasil de um contexto de alta inflação para o de estabilidade de preços teve impactos importantes nas transformações do setor bancário brasileiro. Os bancos tornaram-se eficientes na intermediação financeira e na geração de resultados, respondendo de forma dinâmica a este cenário de estabilidade monetária, conseguindo a manutenção de seus elevados níveis de rentabilidade. Entretanto, essas instituições se mostram ineficientes na contribuição para o financiamento do desenvolvimento no que se refere à integração de parcela importante da população ao mercado de crédito e de serviços financeiros, ou seja, mesmo depois da estabilização monetária, os bancos brasileiros não têm cumprido o papel de dinamizar o ciclo de negócios. Parte deste resultado, verificado ao longo deste trabalho, se deu como resposta à dinâmica do sistema financeiro internacional.

Nos termos de Keynes (1930), na análise do crédito no Brasil, os bancos têm dado preferência à circulação financeira em detrimento da circulação industrial. Isso se deve às especificidades dos títulos públicos federais: ativos que combinam elevados níveis de liquidez e rentabilidade ao mesmo tempo. A existência desses ativos permite ao sistema bancário no Brasil obter elevados níveis de rentabilidade a partir de uma composição de portfólio flexível, capaz de responder de maneira espontânea às oportunidades de lucro percebidas pelos bancos.

Dessa forma, verificou-se neste trabalho, a partir da análise de dados do consolidado bancário no Brasil, que ao invés de cumprir um papel de estabilizador no sistema, os bancos são agentes instabilizadores, que retraem a oferta de crédito quando percebem a retração da economia, aumentando sua preferência pela liquidez. Quando analisados os bancos privados percebe-se, ainda, que o ajuste de portfólio nos momentos de estabilidade é muito menos pró-crédito do que o esperado, se tomarmos como parâmetro os outros sistemas bancários. No que tange aos bancos públicos, pode-se dizer que eles que sustentam a oferta de crédito nos momentos de crise e, além disso, sustentam a oferta de crédito de áreas que o sistema privado não atua. Os bancos estrangeiros, por sua vez, atuam mais como "especuladores" do que como "emprestadores" e isto se deve ao fato de que a questão central do setor privado é a de gerar a máxima rentabilidade possível com alguma margem de segurança e liquidez, independentemente da geração, ou não, de crédito. 
Assim, sob a abordagem de Minsky (1986), a análise do período selecionado nos mostra que há ajustes cíclicos dos bancos brasileiros e, além disso, há um limite à expansão do crédito mesmo em períodos de estabilidade. Esses ajustes cíclicos dos bancos instalados no Brasil ficam evidentes quando se compara os momentos em que se tem um maior volume de crédito com os momentos em que existe um contexto internacional favorável, com alta liquidez internacional e um fluxo de capitais estrangeiros destinados ao país em volume significativo. Quando essa situação internacional muda, os bancos se retraem, diminuindo a oferta de crédito justamente no momento em que os agentes mais necessitam de recursos para saldar seus compromissos.

Especificamente durante a crise financeira internacional de 2008/2009, os bancos públicos assumiram o papel fundamental de ofertar créditos específicos (sobretudo agroindustriais e imobiliários), necessários para a promoção do crescimento econômico. Sendo assim, a oferta de crédito de longo prazo se encontra atualmente limitada pela atuação de bancos públicos, ao passo que bancos privados nacionais e estrangeiros adotam posturas severamente especulativas, guiadas pela dinâmica do capital internacional.

Portanto, este trabalho procurou mostrar que a atuação dos bancos na economia brasileira está de certa forma subordinada às flutuações cíclicas pelas quais a economia internacional passa, de modo que sempre que ocorre uma reversão do ciclo econômico há um rebatimento quase que imediato na conta financeira do Brasil e, consequentemente, no seu volume de crédito ofertado pelo sistema bancário. Mesmo não existindo uma relação direta de causalidade entre essas duas variáveis (saldo da conta financeira e volume de crédito), elas acabam tendo praticamente os mesmos determinantes. Se o saldo da conta financeira depende do humor dos investidores internacionais e de expectativas favoráveis para ser positivo, o volume adequado de crédito ofertado depende do humor dos grandes bancos e de uma perspectiva otimista acerca do comportamento da economia. Entretanto, dado o caráter incerto da economia, os agentes nem sempre acertam suas expectativas, o que os faz mudar de postura várias vezes durante o ciclo econômico, de modo que quanto mais agentes especulativos e Ponzi estiverem presentes na economia, mais instável será, e quanto mais agentes hedge presentes, menos eles estarão dispostos a correr riscos, possuindo uma preferência pela liquidez maior e mais estável será essa fase do ciclo.

\section{Referências}

ADACHI, V.; BALARIN, R. Banqueiros despistaram a vizinhança. Valor Econômico, São Paulo, 4 nov. 2008.

BANCO CENTRAL DO BRASIL. Notas metodológicas do balanço de pagamentos. Notas técnicas do Banco Central do Brasil, Brasília, n. 1, p. 1-16, jun. 2001. 
CARVALHO, F. C. Moeda, produção e acumulação: uma perspectiva pós keynesiana. In: SILVA, M. L. (Org.). Moeda e produção: teorias comparadas. Brasília: UNB, 1992.

CARCANHOLO, M. D. Desregulamentação e abertura financeira: repercussões sobre a autonomia de política econômica e as crises cambias. Economia Ensaios, Uberlândia, v. 15, n. 2, 2001.

CHICK, V. The evolution of the banking system and the theory of saving, investment and Interest. Economies et societées, 20, serie Monnaie et Production, p.111-26. In: ARESTIS, P.; DOW, S. (Ed.). Money, method and Keynes: selected essays of Victoria Chick. London: Macmillan, 1992. p.193-205.

CINTRA, M. A. M.; PRATES, D. M. Os fluxos de capitais para o Brasil nos anos 90. In: Lacerda, A. C. (Org.). Crise e oportunidade: o Brasil e o cenário internacional. São Paulo: Sobeet: Lazuli, 2005.

CINTRA, M. A. M. A reestruturação patrimonial do sistema bancário brasileiro e os ciclos de crédito entre 1995 e 2005. In: CARNEIRO, R. (Org.) A supremacia dos mercados e a política econômica do governo Lula. São Paulo: Unesp, 2006. p. 321-346.

FARHI, M. As economias emergentes e os ciclos de liquidez. Boletim Política Econômica em Foco, Campinas, v. 3, p. 25-34, 2004.

FREITAS, M. C. P. Os efeitos da crise global no Brasil: aversão ao risco e preferência pela liquidez no mercado de crédito. Estudos Avançados, v. 23, n.66, 2009.

FUNDAP. Os fluxos de capitais para a economia brasileira em 2008. Debates Fundap, São Paulo, 2009. Disponível em: <http://www.fundap.sp.gov.br/debatesfundap/pdf/conjuntura/ Os\%20 fluxosdecapitaisparaaeconomiabrasileiraem2008.pdf> . Acesso em: 17 jun. 2010.

GABRIEL, L. F.; OREIRO, J. L. Fluxos de capitais, fragilidade externa e regimes cambiais: uma revisão teórica. Revista de Economia Política, São Paulo, v. 28, n.2, p. 331-357, abr.jun. 2008.

IEDI. A crise internacional e a economia brasileira: o efeito-contágio sobre as contas externas e o mercado de crédito em 2008. 2009. Disponível em: < http://www.iedi.org.br/admin_ori/ pdf/20090407_crise.pdf>. Acesso em: 12 maio 2010.

KEYNES, J. M. A Treatise on money. London: Macmillan, 1930.

. Teoria geral do emprego, do juro e da moeda. São Paulo: Atlas, 1982.

MINSKY, H. P. Stabilizing and unstable economy. New Haven: Yale University Press, 1986.

MUNHOZ, V. C. V.; CORREA, V. P. Volatilidade dos fluxos financeiros no Brasil: uma análise empírica por meio do Modelo ARCH (Autoregressive Conditional Heteroskedastic Model). Análise Econômica, Porto Alegre, ano 27, n. 52, p. 201-232, set. 2009.

OREIRO, J. L. Preferência pela liquidez, racionamento de crédito e concentração bancária: uma nova teoria pós-keynesiana da firma bancária. In: ENCONTRO DA SOCIEDADE BRASILEIRA DE ECONOMIA POLÍTICA, 8, Florianópolis, 2004. Anais... Florianópolis: SEP, 2004.

PAULA, L. F. R.; ALVES JR, A. J. Comportamento dos bancos, percepção de risco e margem de segurança no ciclo minskiano. Análise Econômica, Porto Alegre, v. 21, n. 39, p. 137-162, 2003.

. Bancos e crédito: a abordagem pós-keynesiana de preferência pela liquidez. Revista

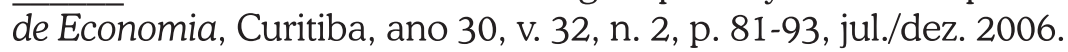


PLIHON, D. A ascensão das finanças especulativas. Economia e Sociedade, Campinas, n.5, dez. 1995.

PRATES, D. M. As assimetrias do sistema monetário e financeiro internacional. Revista de Economia Contemporânea, Rio de Janeiro, v. 9. n. 2, maio/ago. 2005.

. A inserção externa da economia brasileira no governo Lula. In: CARNEIRO, R. (Org.). A supremacia do mercado. São Paulo: FAPESP: UNESP, 2006.

Os fluxos de capitais para a economia brasileira em 2007 e no primeiro quadrimestre de 2008. In: BLASOTO JUNIOR, G.; NOVAIS, L. F; FREITAS, M. C. P. (Org.). Panoramas das economias internacional e brasileira: dinâmica e impactos da crise global. São Paulo: FUNDAP, 2009.

PRATES, D. M.; BIANCARELI, A. M. Panorama do ciclo de crédito recente: condicionantes e características gerais. 2009. Projeto de estudos sobre as perspectivas da indústria financeira brasileira e o papel dos bancos públicos. Disponível em: <http://www.bndes.gov.br/SiteBNDES/export/sites/default/bndes_pt/Galerias/Arquivos/empresa/pesquisa/SubprojetoII.2_ PIF.pdf $>$. Acesso em: 12 maio 2010 .

RESENDE, M. F.; AMADO, A. Liquidez Internacional e ciclo reflexo: algumas observações para a América Latina. Revista de Economia Política, São Paulo, v. 27, n. 1, p.41-49, jan./mar. 2007.

STIGLITZ, J.; WEISS, A. Credit Rationing in Markets with Imperfect Information. American Economic Review, Nashville, v. 71, n. 3, p. 393-410, 1981.

Recebido em: 11/11/2010.

Aceito em: 23/10/2011. 